\title{
Do Managers Withhold Good News from Labor Unions?
}

\author{
Richard Chung \\ Griffith University, Australia \\ Bryan Byung-Hee Lee \\ University of Macau, Macau \\ Woo-Jong Lee* \\ The Hong Kong Polytechnic University, Hong Kong \\ Byungcherl Charlie Sohn \\ City University of Hong Kong, Hong Kong
}

January 2013

\begin{abstract}
With scarce empirical support, prior literature argues that managers tend to withhold good news and promote bad news to preserve their bargaining power against labor unions. This paper provides evidence on this rarely supported argument. Using comprehensive firm-level data in Korea where labor unions have a long tradition of making credible threats, we find that overall disclosure frequency is negatively related to labor union strength, and that this relation is more pronounced in firms with good news. We also find that firms with strong labor unions withhold good news during the labor negotiation period and release it in an abrupt fashion afterwards and this pattern is more prominent than that of the firms with weak or no unions, implying that managers time news disclosure considering bargaining schedules to achieve better outcomes in labor negotiations. These results are robust to a battery of sensitivity tests.
\end{abstract}

Key Words: Labor Union, Disclosure, Timing Disclosure

JEL classification: G14, J50, M41, M54

\footnotetext{
* Corresponding author, E-mail: afwjlee@polyu.edu.hk, Tel: +852-2766-4539

For their valuable comments and suggestions, we thank Kenneth Borokhovich, Peter Cheng, Jong-Hag Choi, Scott Fung, Simon Fung, In-Mu Haw, Soo Young Kwon, Justin Law, Jay Junghun Lee, Sidney Leung, Jiang Li, James Ohlson, Nancy Su, Joseph Weintrop, Yong Yu, and seminar participants at the 2012 American Accounting Association's annual meeting, Griffith University, and Hong Kong Polytechnic University. We also thank Jinha Park and Hoshik Shim for their excellent research assistance.
} 


\section{Do Managers Withhold Good News from Labor Unions?}

\section{Introduction}

Managers facing organized labor often take strategic actions to lower a firm's perceived ability to meet a wage demand. Such managers tend to hold less cash (Klasa, Maxwell, and Ortiz-Molina, 2009), cut dividends (DeAngelo and DeAngelo, 1991), manage earnings downward (DeAngelo and DeAngelo, 1991), miss analysts' forecasts (Bova, 2012), and strategically choose accounting methods (Bowen, Ducharme, and Shores, 1995; Cullinan and Bline, 2003; D’Souza, Jacob, and Ramesh, 2000) to project a negative picture and, as a result, better cope with labor's wage demands. In a similar vein, earlier research argues that such managers are reluctant to share information on firms' prospects with labor so as to preserve bargaining power (Kleiner and Bouillon, 1988; Leap, 1991; Hilary, 2006). Surprisingly, however, empirical evidence to support the claim that management strategically shares information with labor unions is scarce. This paper, thus, aims to fill this gap by exploring strategic disclosure policies of unionized firms.

We posit that managers facing organized labor tend to disclose less on average, and that they withhold good news and promote bad news to paint a pessimistic picture about the firms' prospects. We also predict that this asymmetric news disclosure is more prominent during the collective bargaining process than it is during other periods of the year. Consistent with the prediction, we find strong evidence that labor union strength is negatively associated with disclosure frequency using a large sample of Korean listed firms for the 2003-2007 period. Furthermore, we report that this negative association between union strength and disclosure frequency is mainly driven by good news firms. We also find that mangers time news disclosure 
by withholding good news during the labor bargaining period and then releasing it in an abrupt fashion when the bargaining is over. Withholding good news during the labor negotiation period stems from managers' strategic disclosure policy, which is intended to reduce the excessive surrender of the company resources to the unions. Our main findings are robust to a different classification of news contents, endogeneity control for union strength, and various sensitivity tests.

In establishing the empirical association between labor union and disclosure activities, we particularly benefit from Korean contexts for the following reasons. First, Hilary (2006) argues that using raw disclosure may not capture the whole information flow because management can reveal information to financial markets through various alternative channels. However, the regulatory body of Korea, the Financial Supervisory Service (FSS, similar to the SEC in the U.S., http://englishdart.fss.or.kr/) requires all Korean listed companies to disclose their material information to the public simultaneously before they provide the information to a limited number of market participants such as financial analysts, institutional investors, foreign investors, etc (KSE 2002; KRX 2005). ${ }^{1}$ In so doing, disclosing firms have to file details of their disclosure on the Korea Investor's Network for Disclosure (KIND) System which is operated by the Korean stock market, as well as on the Data Analysis, Retrieval and Transfer (DART) System which is operated by the FSS. We term this Reg FD(Regulation Fair Disclosure). As a result of Reg FD, important corporate information relevant to firm value must be disclosed in a fair and timely manner. This naturally enables us to address Hilary's (2006) concern because the Reg FD rules preclude other sources of information flow from Korean firms to the public and thereby making

\footnotetext{
${ }^{1}$ The Korean stock market specifies the "material" information subject to Reg FD by disclosure regulation. It includes "Future Business \& Management Plan", "Forecasts of Sales, Operating Income, Continuing Business Income Before Tax (or Ordinary Income), or Net Income", "Preannouncement of Sales, Operating Income, Continuing Business Income Before Tax (or Ordinary Income), or Net Income" and "Major Managerial Issues" (KSE 2002; KRX 2005).
} 
their fair disclosures the only outcome of firms' strategic disclosure policy.

Besides the advantage of an empirical proxy for disclosure quality, we also have good reasons to pay attention to Korean companies. In the U.S., empirical evidence on labor unions has been largely scarce because no comprehensive firm-level measure of unionization rate is yet available. $^{2}$ In contrast, Korean listed firms are required to report the number of union workers in their annual reports from which we can retrieve comprehensive firm-level unionization rate for each firm in a given year. This study thus takes advantage of such a unique disclosure requirement in Korea.

Furthermore and more importantly, the labor union plays a significant role as a nonfinancial stakeholder in Korea. In an annual report published by the World Economic Forum (WEF) in 2009, South Korea fell six places in global business competitiveness, landing $19^{\text {th }} 3$ The WEF attributed the decline in part to the difficulty of hiring and firing employees, which leaves employers to work out temporary employment contracts. On the WEF's labormanagement relations list, Korea ranks the $3^{\text {rd }}$ to the last. With their proud tradition of fierce protests harking back to their resistance against the military dictatorships of the 1970s and 80s, labor unions in Korea still remain radical and often militant. ${ }^{4}$ Accordingly, labor unions' threats are perceived as highly credible in Korea, which provide sufficient incentives for management to initiate actions against such threats. To the extent that the unionization rate validly proxies for the

\footnotetext{
${ }^{2}$ With admitting this potential limitation, some recent papers have employed industry level measures of unionization rate based on survey data for U.S. firms (Chen, Kacperczyk, and Ortiz-Molina, 2011; Hilary, 2006; Matsa, 2010). For example, to measure labor strength, Hilary (2006) uses the interaction of the industry-level unionization rate (i.e., the percentage of employees in the 3-digit industry who are represented by a union) and the firm-level labor intensity (i.e., the firm's number of employees scaled by total assets). More recently, other studies try to construct the firm-level data by aggregating establishment-level data from the FMCS (Federal Mediation and Conciliation Service) but it is also far from comprehensive. Note that Chyz, Leung, Li, and Rui (2011) identify less than 300 distinct firms from FMCS. Notably, this "estimated" firm level proxy for unionization rate can suffer from nontrivial measurement errors.

3 See "Union's Absurd Demands Only Jeopardize Korean Auto Industry (Chosunilbo, 22 March 2010)", available at http://english.chosun.com/site/data/html dir/2010/03/22/2010032200780.html.

4 "Militant Labor Activism Can't Protect Jobs (Korea Focus, 10 August 2009)", available at http://www.koreafocus. or.kr/design2/layout/content print.asp?group_id=102694.
} 
magnitude of these threats, we expect that a Korean sample would provide us with a more powerful test. $^{5}$

Our findings add to the disclosure literature in several ways. Healy and Palepu (2001) note the absence of evidence in the literature about the effect of agency problems on corporate disclosures. We contribute by showing how agency problems, attributable to the informational dynamics between management and employees, affect disclosure strategy. In a recent paper, Bova (2012) documents that, in the face of organized labor force, managers tend to miss analysts' consensus forecasts by taking less action to guide forecasts downward when estimates are too high, but more action to deflate earnings when expectations are too low. By focusing on fair disclosures, this paper expands the scope of disclosure to a broader level which takes place even before managers communicate with analysts.

Our paper also complements Hilary's (2006) findings on the positive association between labor union strength and information asymmetry by suggesting a specific channel how information asymmetry of unionized firms becomes more severe in financial markets. We also contribute to the literature on disclosure costs. Apart from the potential benefits of disclosures (e.g., reduced cost of capital), there are also costs if the disclosures reveal proprietary information about the firm's prospects to related parties such as business competitors (Verrecchia, 2001). We contribute to this stream of research by identifying employees as another important information user especially when they exhibit excessive rent-seeking behavior. Recognizing the incentives and behaviors of management and labor unions is particularly important for both parties in the labor negotiation process. We also contribute to the research stream on mangers' "timing" of information flow. DeAngelo and DeAngelo (1991) document that firms report lower

\footnotetext{
${ }^{5}$ Similarly, Lara, Manuel, Osma, and Mora (2005) attribute persistent income decreasing strategies in code law countries to the existence of strong labor unions.
} 
income and cut dividends during union negotiations. According to Chen and Mohan (1994), managers are more likely to change earnings announcement dates when the earnings are less than expected. In contrast, Liberty and Zimmerman (1986) do not find evidence that managers conduct income-decreasing earnings management during labor negotiations. Bova (2012) finds that unionized firms are more likely to miss mean consensus analysts' earnings forecasts to signal a negative outlook to their unions, but this tendency is not restricted to the period just before the labor negotiation process. We add a piece of evidence supporting managerial timing of disclosure in the context of labor relations by showing that managers in unionized firms withhold good news during the collective bargaining process and then release it in an abrupt fashion subsequently.

More importantly, we specifically propose asymmetric disclosure behaviors to withhold good news and promote bad news in unionized firms. While various incentives can motivate management to release or withhold their private information (Healy and Palepu, 2001; Verrecchia, 2001), the incentive to withhold good news and promote bad news has not been frequently discussed in the literature. The only exception is that managers do so in the period immediately preceding option grant dates to lower the exercise price of their options (Yermack, 1997; Aboody and Kasznik, 2000). ${ }^{6}$ On the other hand, there is abundant evidence that management has incentives to withhold bad news for various reasons, such as career concerns (Nagar, Nanda, and Wysocki, 2003; Kothari, Shu, and Wysocki, 2009). By focusing on their incentives to gain favorable terms in the labor negotiation process, we add a new piece of evidence to this literature on very rare cases in which management withholds good news and promotes bad news.

\footnotetext{
${ }^{6}$ One may consider managers' tendency to quickly disclose bad news to reduce litigation risk as another exception but this case does not necessarily require management to withhold good news (Skinner, 1994; 1997).
} 
This paper is organized as follows: Section 2 reviews prior literature and develops the main research hypotheses; Section 3 explains variable measurements and the empirical design; Section 4 describes our data and sample and provides the main empirical results; Section 5 conducts sensitivity tests; and Section 6 concludes.

\section{Related Literature and Hypothesis Development}

\subsection{Labor Union and Disclosure}

There is a stream of research on the unions' role in diverse corporate decisions on operating, financing, and investing activities. Empirical research on the effect of labor unions on firm performance typically addresses the related operating productivity or costs. Previous findings suggest a trade-off between the costs and benefits of a labor union with regard to its effect on firms' operating profitability. A labor union typically has a positive effect on the productivity of a firm (Bronars and Deere, 1994; Hirsch, 1991). However, the effect of unions on the improvement of productivity is offset by escalated labor compensation costs, eventually leading to reduced profitability (Bronars and Deere, 1994).

Managers' strategic incentives arising from considerations for favorable bargaining positions against labor unions also have a substantial impact on corporate financing decisions. As maintaining a high level of corporate liquidity can encourage workers to raise their wage demands, a firm with external finance constraints has an incentive to use the cash flow demands of debt service to improve its bargaining position with workers (Matsa, 2010). Such liquidity concern also motivates managers to hold less cash in order to shelter corporate income from labors' demands (Klasa et al., 2009). 
The research also consistently shows that labor unions influence investment decisions. For example, unions limit the level and riskiness of firms' investments (Bronars, Deere, and Tracy, 1994). The rationale for this empirical regularity is that because unions are rent-seekers, they use the threat of a strike to appropriate quasi-rents that would otherwise flow to investments (Hirsch, 1992), thus reducing management's incentives to make risky investments.

Hilary (2006) investigates the effect of labor union strength in terms of its capital market consequences. Using several proxies for information asymmetry, he documents a positive association between labor union strength and information asymmetry. However, he does not investigate the direct channel through which managers facing strong labor unions bring about information asymmetry in the financial market. In sum, labor unions play a significant role in key aspects of corporate decisions and give rise to important capital market consequences.

Despite labor's impact on diverse corporate decisions and market consequences, much less is known about its impact on firms' disclosure policy. Various incentives can motivate managers to disclose or withhold their private information (Healy and Palepu, 2001; Verrecchia, 2001). Managerial commitment to quickly and fully disclose private information, good or bad, can reduce information asymmetry (Glosten and Milgrom, 1985; Diamond and Verrecchia, 1991; Verrecchia, 2001; Healy and Palepu, 2001), which in turn increases firm value. ${ }^{7}$ However, existing theories suggest that disclosure costs that arise from the proprietary nature of

\footnotetext{
${ }^{7}$ Information asymmetry exists when certain investors (informed investors) have private information on a firm, whereas others (uninformed investors) do not. The level of information asymmetry is important in capital markets because uninformed investors require compensation for taking risks in trading with informed investors, which indicates that information asymmetry is positively related to the cost of capital. Diamond and Verrecchia (1991) suggest that more frequent disclosure results in greater liquidity because of reduced information asymmetry, which in turn lowers the cost of capital. Merton (1987) offers the Investor Recognition Hypothesis, which posits that investors with insufficient knowledge of a certain firm (i.e., uninformed investors) will not purchase that firm's stock. Accordingly, if greater disclosure activity enables investors to assess a firm's value more accurately and reduces the cost of processing firm-specific public information, such activity will induce more uninformed investors to trade the firm's stock. In sum, the negative association between disclosure activity and information asymmetry is evident in both theoretical and empirical studies.
} 
information may sometimes prevent full disclosure (Verrecchia, 2001). When disclosure is costly to the firm, a manager attempting to maximize firm value will disclose information only if it is favorable (e.g., Verrecchia, 1990). Managers know that the labor unions actively collect and use firms' information on operating, financing, and investing activities and the related outcomes to enhance their wage negotiation ability. Therefore, labor unions apparently generate costs regarding managers' full disclosure. As a result, managers facing organized labor take strategic actions when deciding whether and how much information to disclose. ${ }^{8}$ The above discussions lead to our first testable hypothesis (in alternative form):

H1: Managers' disclosure frequency decreases with the strength of the labor union, ceteris paribus.

\subsection{Labor Union and Asymmetric Disclosure}

Related studies document several incentives to withhold a certain type of news (i.e., asymmetric disclosure behaviors). Managers have incentives to withhold bad news relative to good news under a standard agency problem where managerial disclosure preferences are not aligned with those of shareholders (Healy and Palepu, 2001; Verrecchia, 2001; Kothari et al., 2009). This differential disclosure incentive stems from a variety of factors, including formal compensation contracts, career concerns, reputation concerns, and empire building (Ball, 2009;

\footnotetext{
${ }^{8}$ On the other hand, as Jensen and Meckling (1976) argue, if unions become entrenched and force extreme underinvestment and/or extract too much rent, then agency costs increase and the overall stakeholders, including unions, are worse off. Thus, under the rent-seeking theory, unions can be effective monitors as long as they are not entrenched. A recent study provides additional support for unions' monitoring role. Among others, Chen et al. (2010) argue that because union workers' contractual wages and benefits are similar to the payoff on risky debt, unions are likely to have preferences similar to those of bondholders. If so, the union strength will limit managerial actions that shift wealth away from bondholders, who accordingly charge a lower cost of debt. Consistent with this argument, they report that the cost of debt decreases with union strength, implying that unions reduce agency costs of debt. Based on such a monitoring role of labor unions, one may predict a positive association between labor union strength and disclosure quality. However, it is difficult to believe that unions can indeed participate in disclosure decisions and force management to disclose more. Rather, it is more reasonable to posit that managers consider the possible role of the labor force in deciding whether and how much they disclose.
} 
Graham, Harvey, and Rajgopal, 2005; Khan and Watts, 2009; LaFond and Watts, 2008). For these reasons, managers often delay bad news disclosures in practice (Graham et al., 2005).

Relative to the abundant evidence for incentives to withhold bad news, evidence for the opposite (i.e., incentives to withhold good news) remains few and far between. To our knowledge, two exceptions can explain why managers promote bad news and delay good news disclosure. First, litigation risk can motivate managers to quickly reveal bad news as they face a greater loss function with bad news (Kasznik and Lev, 1995; Skinner, 1994, 1997; Baginski, Hassell, and Kimbrough, 2002). Second, managers do so in hope of influencing the exercise price of their options (Yermack, 1997; Aboody and Kasznik, 2000).

We propose labor union strength as the third motive that induces managers to delay good news and prompt bad news disclosures. Hilary (2006) cites evidence which suggests that revealing information in a unionized environment weakens management's position during the collective bargaining process. It is particularly true if a firm creates a sufficient rent as labors are quasi rent-seekers. We thus expect that managers' tendency not to reveal private information is more pronounced in firms with good news, leading to cross-sectional differences in disclosure activities across good versus bad news firms. Based on this reasoning, we formalize our second hypothesis (in alternative form):

H2: Managers' disclosure of good (bad) news decreases (increases) with the strength of the labor union, ceteris paribus.

\subsection{Labor Union and Disclosure Timing}

Prior literature examines managerial timing in various arenas. For example, DeAngelo and DeAngelo (1991) document that firms report lower income and cut dividends during the 
labor negotiation process. In contrast, Liberty and Zimmerman (1986) do not find evidence that managers conduct income-decreasing earnings management during labor negotiations. Chen and Mohan (1994) document that managers are more likely to change earnings announcement dates when earnings are less than expected, and that this tendency is more pronounced in small firms. More closely related papers to our study are Yermack (1997) and Aboody and Kasznik (2000). They report that managers withhold good news and promote bad news in the period immediately preceding option grant dates to lower the exercise price of their options. However, prior studies on disclosure timing, especially in terms of labor relations, are relatively scant. Bova (2012) finds that unionized firms are more likely to miss analysts' earnings forecasts using both earnings management and expectations management to signal a negative outlook to their unions, but this tendency is not restricted to the period just before the labor negotiation process. Though his paper focuses on firms' meet-or-beat forecast strategy rather than on comprehensive news disclosures, it motivates us to draw another interesting prediction.

In previous sections, we have considered the effect of union strength on the average level of news disclosure throughout the year. However, managers not only reduce (increase) the annual level of good (bad) news disclosures facing strong labor unions but also can time when to intensify and relax such asymmetric news disclosures taking labor negotiation schedules into account. In other words, managers can withhold good news and promote bad news during the collective bargaining process to a greater extent than during other periods of the year. However, mangers cannot withhold good news forever and will release it to the market in an abrupt fashion when the bargaining process is over. Similarly, the accelerated announcement of bad news during the bargaining process will cause an abnormal decrease of bad news disclosures subsequently. We expect that this temporal pattern of asymmetric disclosure within a year will be more 
prominent for the firms with stronger labor unions. Unlike U.S. firms, Korean firms engage in yearly collective bargaining. Since the vast majority of Korean firms follow Japanese tradition of Shunto to bargain in the second calendar quarter of the year, ${ }^{9}$ we can test this within-year temporal pattern of the asymmetric disclosure in the spirit of an event study. We formalize this test as our third hypothesis (in alternative form):

H3: Managers' disclosure of good (bad) news decreases (increases) during the collective bargaining process with subsequent reversals, and this timing of asymmetric news disclosure is more pronounced for firms with stronger labor unions, ceteris paribus.

\section{Research Design}

To test our main hypotheses, we follow prior studies for regression specification. As recognized by Larcker and Rusticus (2010), however, a complete structural determinant model of disclosure quality has not been developed. Healy and Palepu (2001) suggest various motives for voluntary disclosure such as capital market transactions, corporate control, stock compensation, litigation, management talent signaling, and proprietary cost. We adopt equity offer dummy to control for capital market transaction motives (Lang and Lundholm 1993). We include return on assets (ROA), loss dummy, and contemporaneous stock return to control for managers' concerns about the firm performance because of corporate control problems (Warner, Watts, and Wruck, 1988; Morck, Shleifer, and Vishny, 1990; DeAngelo, 1988), and firm size, and industry dummy to control for their concerns about takeover threats (Brennan, 1999). We also control for managers' concerns on the proprietary cost by including the Herfindahl-Hirschman index on the rationale that the proprietary cost incurred by disclosures is larger when industry competition is

\footnotetext{
${ }^{9}$ This collective bargaining is called "spring labor offensive" or "shunto" because it falls in spring every year. See "South Korea's Workers Return to the Streets (The Economist, 29 April 1999)", available at http://www.economist.c om/node/202276.
} 
intense (Verrecchia, 2001; Dye, 2001). We also include the control variables adopted in Larcker and Rusticus (2010), which are the natural logarithm of the number of shareholders, length of operating cycle, the presence of a Big auditor, book-to-market ratio, number of analysts following the firm, and leverage. We add a Chaebol dummy and foreign ownership because they may be important factors affecting the corporate governance of Korean firms. Specifically, we estimate the following regression to test our main hypotheses:

$$
\begin{aligned}
& D E P_{i t}=a_{0}+a_{1} \text { Union }_{i t}+a_{2} \log (\# \text { Owners })_{i t}+a_{3} \text { Offer }_{i t}+a_{4} R E T_{i t}+a_{5} \text { Loss }_{i t}+a_{6} H H I_{i t} \\
& +a_{7} \text { OpCycle }_{i t}+a_{8} \text { BigAudit }_{i t}+a_{9} \text { Size }_{i t}+a_{10} B M_{i t}+a_{11} \log (\# \text { Analysts })_{i t}+a_{12} \text { LEV }_{i t} \\
& +a_{13} \text { ROA }_{i t}+a_{14} \text { Chaebol }_{i t}+a_{15} \text { ForOwn }_{i t}+\sum \text { Year }+\sum \text { Ind }+\varepsilon_{i t}
\end{aligned}
$$

where $D E P=\log (\#$ Disclosures $)$ is the natural logarithm of one plus the number of disclosures for firm $i$ in year $t$ in testing H1. To gauge labor union strength (Union), which is the variable of our main interest, we define two measures - union existence and unionization rates. Union, thus, equals either unionization rate (which is the proportion of the number of union members to the number of total employees), or the union existence (which equals one if some employees are union members, and zero otherwise). ${ }^{10}$ The detailed definitions of all the variables are summarized in Appendix A. We estimate Eq. (1), which includes year and industry fixed effects, using pooled regressions with standard errors clustered at the firm level (Petersen, 2009). ${ }^{11,12}$ Hypothesis 1 predicts that coefficient $a_{1}$ is negative.

\footnotetext{
${ }^{10}$ Litigation risk also influences the incentive for corporate disclosure (Skinner, 1994). We expect stock returns, loss indicators, ROA, firm size and industry dummies to sufficiently capture the litigation risk of a firm as in prior studies (Simunic, 1980). However, it should be noted that Korea is a code law country with a strong German law origin and Korean firms are therefore rarely exposed to shareholder litigation (La Porta, Lopez-De-Silanes, and Shleifer, 2006).

${ }^{11}$ For industry classification, we rely on a 3-digit KSIC (Korea Standard Industry Code, which is very similar to SIC) defined by the Bureau of Statistics. We then construct 29 industry dummies to capture industry-specific effects on disclosure activities.

${ }^{12}$ We also repeat all the regressions in this paper using the Fama and MacBeth (1973) method and find that the main implications are unaltered.
} 
To test $\mathrm{H} 2$ and $\mathrm{H} 3$, we classify good news in two different ways. The first way is to classify a firm itself (not individual news) into the good news or other news firm based on its annual summary measures regardless of the content of its individual news. Following Kothari et al. (2009), we define a firm as a good news firm if its analyst-forecast-based earnings surprise exceeds $1 \%$ of actual earnings in a given year. Alternatively, we also define good news firms as those with dividend increases or high sales growth. We divide our sample into good and other news firms and regress Eq. (1) separately for each subsample. Hypothesis 2 predicts that $a_{1}$ is negative in good news subsamples and positive in other news subsamples. ${ }^{13}$

Our method of defining good news, however, may suffer from nontrivial measurement errors. Even though a firm reports a very high positive earnings surprise for example, it may not necessarily have disclosed more good news during the past year. To examine more precisely managers' behavior of withholding good news and promoting bad news when their labor unions are strong, we need to track each piece of news and classify it into good or bad. Therefore, in the second way of defining good news, we manually read the content of each piece of news and classify it into good, bad, or neutral news. See Appendix B for the detailed criteria of news classifications and the examples of good, bad, and neutral news. We redefine $D E P=\log (\# N e w s$ Disclosures) as Log(\#Good News Disclosures) or Log(\#Bad News Disclosures), which are the natural logarithms of one plus the number of good or bad news disclosures for firm $i$ in year $t$, respectively, and regress Eq. (1) for the whole sample. Hypothesis 2 predicts that coefficient $a_{l}$ is negative (positive) for the good (bad) news disclosure.

To test $\mathrm{H} 3$, we redefine $D E P=\log (\#$ News Disclosures $)$ as $\log (\#$ Good News Disclosures) or Log(\#Bad News Disclosures), which are the natural logarithms of one plus the

\footnotetext{
${ }^{13}$ Since we do not classify bad news firms separately using this method, $a_{l}$ could be indifferent from zero instead of positive in the "other news" subsamples.
} 
number of good or bad news disclosures for firm $i$ in "month $m$ ", respectively, and construct an indicator variable Qdum, which takes the value of one if the news is disclosed in the second quarter when most Korean firms do labor negotiations, and zero otherwise. We then interact Qdum with Union to see whether the impact of Union on good and bad news disclosures is different in the second calendar quarter compared to other quarters of the year. Hypothesis 3 predicts that the coefficient on Union*Qdum is negative (positive) for the good (bad) news disclosure.

\section{Empirical Results}

\subsection{Data description}

Our sample covers non-financial companies listed on the Korean Stock Exchange from 2003 to 2007. In our sample period, all listed firms are required to report the number of union members and the number of total employees in the electronic corporate filing services of the Financial Supervisory Services (FSS, equivalent to the SEC in the U.S.). We hand-collect the data to construct the firm-year level unionization rate measures (the fraction of the number of union members to the number of total employees). In addition to the union data, we retract the annual number of disclosure data from the Korea Investor's Network for Disclosure (KIND) System, and financial data and ownership data from two databases developed by the Korea Listed Companies Association (KLCA) and the Korea Investors Service (KIS), respectively. We also read the individual news disclosed by our sample firms from the KIND System and manually classify them into good, bad, or neutral news. The observations are deleted if the data on firm-year level unionization rates or on the main variables used in our analyses are missing. To alleviate concerns over potential problems arising from the existence of extreme outliers, we 
winsorize observations that fall within the top and bottom $1 \%$ of the annual empirical distributions of our major research variables. We follow the standard procedure of dropping the data on financial institutions. After applying these sample selection criteria, we have a final sample of 2,084 firm-years and 372 unique firms during our sample period.

Table 1 Panel A shows that the average unionization rate is $34.3 \%$ in our sample, whereas the average number of disclosures is 2.34 per year. ${ }^{14}$ This indicates that material news disclosure is not a daily management activity for Korean firms. However, its standard deviation is 3.48 , indicating that the variation of disclosure frequency across firms is fairly large. The average number of good and bad news disclosures is 1.22 and 0.39 per year, respectively. One notable observation is the book-to-market ratio $(B M)$. Its mean value is 1.846 , which is well known as the "Korea discount", meaning that the market value is lower than the book value of equity. As shown in many papers (e.g., Black and Kim, 2012), this is a characteristic of the entire sample of Korean listed firms.

Panel B compares firm characteristics across the high versus low unionization subsamples. We divide samples into two by the sample median of unionization rates. This shows that firms with a high unionization rate make fewer disclosures than their counterparts, consistent with our Hypothesis 1. They also disclose less good news and more bad news (the difference is statistically significant), consistent with our Hypothesis 2. They are larger, followed by more analysts, and more likely Chaebol firms as well. Their book-to-market ratio and leverage are also higher. Both firms with high and low unionization rates have a similar degree of market competition $(H H I), \mathrm{ROA}$, and hiring Big auditors. However, these univariate comparisons do not control for other factors affecting disclosure frequency or asymmetric disclosure of good versus

\footnotetext{
${ }^{14}$ We find that 591 firm-year observations have zero union members. To make sure that our results are not driven by these no-union samples, we repeat our analyses after excluding them but the tenor of our findings is unaltered.
} 
bad news. We address this issue in the multivariate regression analyses in the following subsections.

\section{[ INSERT TABLE 1 ABOUT HERE ]}

\subsection{Do Mangers Reduce Disclosures When Facing Strong Labor Unions?}

We investigate the effect of labor union strength on managers' choice of disclosure frequency using Eq. (1) and report the empirical results in Table 2. Column (1) shows that the coefficient on the union existence dummy is negative and significant at the $1 \%$ level $(-0.180$, pvalue $<0.01)$. The result is similar when the continuous variable, unionization rate, is used in column (2). Its coefficient is negative and significant at the $1 \%$ level $(-0.197$, p-value $<0.01)$. The effect of a labor union on the decrease in disclosures is also economically significant. The number of disclosures decreases by $23.5 \%$ when a labor union emerges in a firm, and by $7.7 \%$ when the unionization rate increases by one standard deviation of its distribution, holding other variables at their means. ${ }^{15}$ The adjusted $\mathrm{R}^{2}$ is about $40 \%$, indicating that Eq. (1) is well specified to explain managers' decision regarding disclosure frequency. We use clustered OLS regressions for columns (1) and (2) after taking a natural logarithm of \#Disclosures. However, \#Disclosures is the left-side-censored variable at zero, which violates the assumption of a normal distribution of the dependent variable for OLS. To address this concern, we use negative binominal regressions with the same specifications in columns (3) and (4). ${ }^{16}$ The results are qualitatively similar except that the statistical significance declines to the $6 \%$ level when the unionization rate

\footnotetext{
${ }^{15}$ The mean of the number of disclosures is 2.337 , so its $\log$ value $=\log (1+2.337)=1.205$. When a union emerges, this $\log$ value decreases by 0.18 (the coefficient on union existence dummy), making a new $\log$ value $=1.205-0.18$ $=1.025$. Its raw value $=\exp (1.025)=2.787$, which becomes 1.787 after subtracting 1 . So the percentage change is $(1.787-2.337) / 2.337=-23.5 \%$. In a similar way, $\exp (1.205-0.197 * 0.281)-1=2.157,(2.157-2.337) / 2.337=$ $7.7 \%$, where 0.197 is the coefficient on unionization rate and 0.281 is the standard deviation of unionization rate.

${ }^{16}$ The negative binomial specification is preferred when a dependent variable ranges among nonnegative integers (Rock, Sedo, and Willenborg, 2000). We also redo Eq. (1) using Poisson regressions with raw disclosure frequency data and find that the results of Table 2 hold robust. Using these alternatives does not change the tenor of our findings in subsequent analyses as well.
} 
is used as the main test variable in column (4). In sum, the results in Table 2 are consistent with H1 that managers for firms with stronger labor unions are less likely to make contemporaneous disclosures, possibly to increase their bargaining power during the labor negotiation process.

Turning to the control variables, managers' disclosure propensity increases in the number of shareholders, equity offer dummy, firm size, and analyst coverage, and decreases in the bookto-market ratio. Disclosure frequency also increases for the client firms of Big auditors. This is generally consistent with prior studies (Lang and Lundholm, 1993; Larcker and Rusticus, 2010). The coefficient on the Chaebol dummy is positive and significant in columns (1) and (2) but insignificant in columns (3) and (4). The coefficients on stock return, loss dummy, HerfindahlHirschman index, operating cycle, leverage, ROA, and foreign ownership are insignificant.

\section{[ INSERT TABLE 2 ABOUT HERE ]}

\subsection{Are Managers More Likely to Withhold Good News Disclosures?}

Next, we examine the possibility of the asymmetric effect of union strength on managers' disclosure propensity. Table 3 reports the OLS regression results on the number of disclosure for "Good News" versus "Others" subsamples. The "Good News" subsample consists of firms whose analyst-forecast-based earnings surprises exceed $1 \%$ of actual earnings in Panel A, firms with sales growth greater than the sample median in Panel B, and firms with annual dividend increases in Panel C. The "Others" subsample includes all other firms in the three panels. For brevity, we focus on the results based on the unionization rate. As expected, the coefficient on the unionization rate is -0.199 and marginally significant ( $p$-value $=0.11$ ) for the "Good News" subsample in column (3) of Panel A. Inconsistent with our expectation, however, the coefficient is negative $(-0.166, \mathrm{p}$-value $=0.27)$ for the "Others" subsample in column (4) (this is common in all panels). Though the former is slightly more negative than the latter, their difference is not 
statistically significant. In Panel B, the coefficient on the unionization rate is -0.225 (p-value $=$ 0.02 ) for the "Good News" subsample in column (3), and -0.170 (p-value $=0.05$ ) for the "Others" subsample in column (4). The difference is statistically insignificant. In Panel C, the coefficient on the unionization rate is -0.304 (p-value $<0.01$ ) for the "Good News" subsample in column (3), and -0.103 (p-value $=0.24$ ) for the "Others" subsample in column (4). The difference in their coefficient magnitudes is statistically significant at the $1 \%$ level. The results based on the union existence dummy shown in columns (1) and (2) of each panel are similar. Overall, our second hypothesis (H2) that managers withhold good news and promote bad news to a greater extent when their labor unions are stronger is weakly supported by the results in Table 3. We omit the explanations for the coefficients on control variables in this and following tables since they are qualitatively similar with those reported in Table 2.

\section{[ INSERT TABLE 3 ABOUT HERE ]}

In the above analysis, we assume that the information disclosed during the fiscal year is on average good news when the fiscal year-end earnings beat analysts' consensus forecasts or dividend (sales) increases (grows significantly) from the previous year. Stated differently, the final earnings or sales and dividend news are a representative summary measure of news disclosed during the year. ${ }^{17}$ This way of defining good news, however, may suffer from nontrivial measurement errors. Even though a firm reports a very high positive earnings surprise for example, it may not necessarily have disclosed more good news during the past year. We attribute relatively weak results in Table 3 (especially for bad news analyses) to this measurement error problem. To overcome this limitation, we read the individual disclosures of all the sample firms and classify them into good, bad, or neutral news manually. Panel A of Table

\footnotetext{
${ }^{17}$ Dimitrov and Jain (2011) make a similar assumption in studying managers' good news disclosure before annual shareholder meetings. Since they cannot track individual disclosure and judge whether it is good or bad, they examine stock returns during pre-meeting periods and use them as a representative summary for the average news.
} 
4 shows that on average, $45.0 \%(18.8 \%)$ of the sample firms disclose good (bad) news at least once during the sample period. Similar to earlier findings based on U.S. firms, Korean firms disclose good news more often than bad news (e.g., Lev and Penman, 1990).

The regression results using these data are reported in Panel B of Table 4. For brevity, we only report the results using the unionization rate but the results using the union existence dummy are qualitatively the same. As shown in column (1), when the dependent variable is Log(\#Good News Disclosures), the coefficient on Union is negative and significant at the $1 \%$ level $(-0.178, \mathrm{p}$-value $<0.01)$. In contrast, it is positive (though insignificant) in column $2(0.009$, p-value $=0.80)$ when the dependent variable is $\log (\# B a d$ News Disclosures $)$. We find a similar result using the negative binominal approach in columns (3) and (4). In short, the results using the classification of good versus bad news with more precise methodology support the previous results in Table 3 and more clearly reconfirm our second hypothesis that managers withhold good news and promote bad news disclosures when they face stronger unions.

One may question whether managers can withhold good news from the outsiders in a persistent manner. If the news is material, managers have no way to conceal it forever but to reveal it eventually. The result in Table 4, average lower frequency of good news disclosures for the firms with stronger labor unions, is seemingly inconsistent with this reasoning. To address this concern, we manually reclassify each disclosure into quantitative and qualitative disclosures and repeat the analyses in Table 4 after replacing the dependent variable with Log(\#Quantitative News Disclosures) and Log(\#Qualitative News Disclosures). Unreported results show that the effect of union strength reduces the frequency of qualitative news disclosures to a greater extent than it does that of quantitative ones (statistically significant), and that this phenomenon is more pronounced for good news than for bad news (though not significant). Thus, we conclude that 
our findings in Table 4 are mainly driven by firms' suppressing "soft talks" containing good news which are essentially less material (Hutton et al., 2003).

\section{[ INSERT TABLE 4 ABOUT HERE ]}

\subsection{Do Managers Time Good versus Bad News Disclosures according to Labor Negotiation}

\section{Schedules?}

Our analyses thus far have examined the average disclosure behavior of firms throughout the year. In doing so, we posit that managers can withhold some news (e.g., good news) permanently from labor unions. However, managers can also withhold some news temporarily to weather a collective bargaining schedule given the amount of annual disclosures. It may be more interesting and important to test whether managers constrain (promote) good (bad) news disclosures during the labor negotiation process to a greater extent than during other periods of the year when their labor unions are strong because we claim that managers withhold good news and promote bad news primarily to preserve better positions during the collective bargaining process to cope with labor unions' rent seeking behavior. The results of this analysis are summarized in Table 5. For brevity, we report the results using the unionization rate only but the results using the union existence dummy are qualitatively similar. Columns (1) and (2) report the good news disclosure results, while columns (3) and (4) report the bad news disclosure results. For economy's sake, we report only the results using the negative binominal approach, which is more conservative, but the results using OLS are almost identical. We first regress Eq. (1) without Qdum in column (1). Consistent with the results using firm-year data in Table 4, the coefficient on Union is negative and significant in this firm-month data analysis. When we include Qdum and Union*Qdum in column (2), the coefficient on Union is still negative and significant $(-0.220, \mathrm{p}$-value $=0.02)$. This indicates that managers withhold good news when their 
labor unions are strong even during the non-negotiation period. The coefficient on Qdum is negative but insignificant $(-0.116$, p-value $=0.12)$, implying that there is no distinct seasonal pattern of good news withholding when the unions are weak. More importantly, the coefficient on Union*Qdum is negative and significant at the $1 \%$ level $(-0.425$, p-value $<0.01)$. In contrast, the results for the bad news disclosure in columns (3) and (4) show that the coefficient on Union ${ }^{*}$ Qdum is positive though insignificant $(0.109$, p-value $=0.66)$. Collectively, these results confirm our third hypothesis that the effect of union strength on the decrease (increase) of good (bad) news disclosures is more prominent in the labor negotiation period than in the remaining quarters. $^{18}$

\section{[ INSERT TABLE 5 ABOUT HERE ]}

Figure 1 plots the number of monthly good and bad news disclosures by unionized and non-unionized firms. We can clearly see that the frequency of good news disclosure decreases significantly during the second calendar quarter (i.e., April to June). Even though this pattern is common for both groups (consistent with the insignificantly negative coefficient on Qdum in Table 5), the decrease of good news disclosure during the second quarter is more prominent for unionized firms (consistent with the significantly negative coefficient on Union*Qdum in Table 5). The frequency of good news disclosure returns to its original level after the second quarter,

\footnotetext{
${ }^{18}$ In contrast with our findings, Bova (2012) documents that managers' behavior of missing analysts' forecasts is not concentrated just prior to the collective bargaining process only but observed in a similar level throughout the remaining period. He suggests several reasons: i) it is difficult to specify which period's earnings need to be manipulated since wages are also positively correlated with profitability changes from several previous years, ii) missing analysts' forecasts just prior to the negotiation process becomes less credible over time because labor negotiations are repeated games, iii) it is also important for managers to keep sending bad earnings signals until the bargaining is over, not just prior to it, because it takes time to set mutually agreeable provisions. We think that these concerns are less critical in our setting. Specifically, unlike accounting earnings, news is not a summary measure of a firm's profitability of a specific period but can affect firm value for the unspecified present and future periods. Repeating to miss analysts' forecasts just prior to the bargaining process hardly seems unintentional but good news, especially "soft talks", can be withheld during the bargaining process repeatedly due to either managerial discretion or no existence of good news. Thus, its credibility as a signal decreases over time to a less extent than the meet-orbeat signal. Finally, we include not only the period just before the negotiation process (i.e., early April) but also the whole period of the process (i.e., mid April to June).
} 
showing a pattern of reversal as posited in H3. In contrast, there is no distinct seasonal pattern in bad news disclosures for both unionized and non-unionized firms. However, it seems that the level of bad news disclosures is slightly higher for unionized firms during the second quarter. In sum, this figure reinforces the regression results in Table 5 and supports H3.

\section{[ INSERT FIGURE 1 ABOUT HERE ]}

The reason that managers withhold good news and promote bad news during the labor negotiation process is to preserve advantageous positions against the unions in the wage bargaining process. The implicit assumption behind this reasoning is that managers can deceive employees by manipulating the information flow to market participants (otherwise managers will not repeat this strategy in the long-term). If we show that the average investors in the market also cannot see through managers' opportunistic disclosure strategy, we can buttress this assumption further since employees are also a part of market participants and will be influenced by the behavior of other participants such as investors. To see this, we plot the market-adjusted abnormal monthly returns in Figure 2. The abnormal monthly return decreases significantly during the second calendar quarter for both unionized and non-unionized firms and this decrease is more pronounced for unionized firms, mimicking the monthly good news disclosure pattern observed in Figure 1. This figure is consistent with our assumption that employees do not understand the intention of manipulated news disclosures, and validates our rationale underlying our hypotheses and the previous empirical results.

\section{[ INSERT FIGURE 2 ABOUT HERE ]}

\section{Sensitivity Tests}

\subsection{Addressing Endogeneity Issue}


These findings can have an alternative explanation. Firms are usually less profitable, more financially distressed, and have lower growth potential in the U.S. when their labor unions are stronger (DeAngelo and DeAngelo, 1991; Liberty and Zimmerman, 1986). Thus they have less good news and more bad news to disclose. That is, the lower (higher) disclosure frequency of good (bad) news is not necessarily due to managerial discretion to cope with wage demands but may be due to poorer company fundamentals. If we see Table 1 Panel B, Korean firms are also more leveraged $(L E V)$ and have lower growth potential (i.e., higher $B M$ ) when they have a union or when their unionization rate is higher. However, they are more profitable (even though the difference is statistically insignificant) and more likely to be Chaebol member firms, which implies that the fundamentals of strong union firms are not the same as those of U.S. firms. We have also included in Eq. (1) RET, Loss, and ROA to control for the effect of firm profitability on both union strength and disclosure, $L E V$ to control for the effect of financial distress, and $B M$ to control for the effect of growth. Nevertheless, we try to control for the possible endogeneity of union strength more formally using 2SLS regressions. It is not easy to find a good instrumental variable for this method. Fortunately, however, we do have it for Korean data, which is the ratio of the number of female employees to the number of total employees (Female). When the number of female employees is larger in a firm, its union tends to be weaker. That is, the firm is less likely to have a union and, if it does, its unionization rate is lower (e.g., Antos et al., 1980; Hirsch, 1980). In contrast, there is no theoretical or empirical evidence that can establish a relation between the female worker ratio and disclosure frequency. In short, the female worker ratio is strongly correlated with union strength but minimally correlated with managerial disclosure. 
We regress the union existence dummy or unionization rate on Female and other explanatory variables such as firm size (Size), leverage (LEV), ROA, loss dummy (Loss), and year and industry fixed effects in the first stage regression and report the results in Pane A of Table 6. We adopt Female and industry dummy following Antos et al. (1980) and Hirsch (1980) with other common firm characteristics to potentially affect the degree of unionization. As expected, the coefficient on Female is significantly negative. Specifically, it is -0.737 and -0.192 in column (1) for union existence and column (2) for unionization rate, respectively, both significant at the $1 \%$ level. As for control variables, larger, higher leveraged firms are more likely to be strongly unionized. Profitability is not statistically related to union strength. Using the fitted value of Union, we repeat our main analyses in Tables 2 and 4 and report the results in Panels B and $\mathrm{C}$ of Table 6, respectively. The coefficient on the fitted value of Union is still negative and significant for both columns (1) and (2) in Panel B, consistent with H1. Its magnitude is even larger than that of the corresponding coefficient in Table 2. This indicates that managers' general tendency of reducing disclosures when their unions are stronger is maintained after controlling for the endogeneity of union strength. The second stage regression results using more refined classifications of good versus bad news are similar in Panel C. When we use Log(\#Good News Disclosures) as the dependent variable, the coefficients on the fitted value of Union are significantly negative in both columns, consistent with Table 4 and H2. In sum, the results of robustness tests in this subsection alleviate the concern that our previously reported main results might be driven by the endogenous feature of union strength.

\section{[ INSERT TABLE 6 ABOUT HERE ]}

Another candidate for the endogeneity or correlated-omitted variable problem is product market competition. If firms' investment strategies are more interdependent with their rivals in 
highly concentrated product markets, they prefer a less informative disclosure policy because the proprietary information can be used strategically by their potential competitors (Clarke, 1983; Gal-Or, 1985; Bhattacharya and Ritter, 1983; Brander and Eaton, 1984; Ali, Klasa, and Yeung, 2009). In contrast, firms can also reduce their disclosures when products are good substitutes in highly competitive markets (Darrough, 1993). If firms operating in the oligopolistic industry have stronger unions than those in a standardized consumer product industry, their reduced disclosures may not result from their union strength but from their fear of proprietary information being used by their competitors. However, the level of market concentration proxied by $H H I$ does not differ between high and low unionization firms as shown in Panel B of Table 1, and we already control for $H H I$ in our regression analyses. To address this concern more formally, we partition the total sample into i) high and low HHI firms, ii) consumer product industry and the other industries, and then repeat our main analyses in Tables 2, 4 and 5. We also interact $H H I$ with our Union variable and repeat the main analyses. Unreported results confirm that the main findings in previous analyses are universal across subsamples of differing levels of $H H I$ or two sets of industries, and that the coefficient on Union*HHI is insignificant. This indicates that the negative relation between union strength and disclosure and the effect of union strength on the asymmetric disclosure pattern are not driven by product market competition. ${ }^{19}$

One may also argue that labors are more likely organized in more opaque firms. To address this reverse causality concern, we include the natural logarithm of number of analysts followings in the first stage model regressing UNION against its determinants, and take the residual values for a new proxy for unionization rates. We suppose that the residual values are

\footnotetext{
${ }^{19}$ We also partition our sample into eight industries based on 1-digit KSIC and repeat the main analyses. Our main findings are observed in most of the industry subsamples, indicating that the negative relation between union strength and disclosure frequency and the asymmetric disclosure pattern are not an industry-specific problem.
} 
orthogonal to firms' information environment. We find that our main implications are unaltered when the Union variables are replaced with these residuals.

\subsection{Other Sensitivity Tests}

We conduct a battery of sensitivity tests to check the robustness of our main findings. First, we repeat our main analyses in Tables 2 and 4 using the change specification to alleviate causality concerns. The results are reported in Table 7 . In column (1), we examine whether changes in union existence (i.e., union initiation or union termination) are related to changes in disclosure frequency. We also test whether changes in the unionization rate can explain changes in disclosure frequency in column (2). Note that, in the change specification, we also convert all control variables into change variables. Such first-difference analyses naturally control for firmspecific characteristics that are constant over time, therefore reducing the possibility of a correlated-omitted variable bias. We use $\operatorname{Pr}(\Delta \#$ Disclosures $<0)$ as the dependent variable, which is an indicator variable that takes the value of one if the number of disclosures decreases from the previous year, and zero otherwise. The coefficient on $\Delta$ Union Existence is positive and significant $(2.055, \mathrm{p}$-value $<0.01)$ in column $(1)$, suggesting that union emergence (termination) leads to managers' less (more) frequent disclosures. In column (2), changes in unionization rates significantly explain changes in disclosure frequency. The coefficient on $\Delta$ Unionization Rate is 5.133 and significant at less than the $5 \%$ level. We conduct this change specification tests using the data from the refined news classification method and report the result in columns (3) and (4). Here the dependent variable is $\operatorname{Pr}(\Delta \#$ Good News Disclosures $<0)$, which is an indicator variable that takes the value of one if the number of good news disclosures decreases from the previous year, and zero otherwise. The implications in these columns are similar with those of Table 4; 
that is, managers reduce good news disclosures when the union becomes stronger. In sum, the results using the change specification are consistent with the previous results based on level specification, and mitigate possible concerns about correlated-omitted-variable or weak causality problems.

\section{[ INSERT TABLE 7 ABOUT HERE ]}

We posit that the union existence dummy or the unionization rate captures the real level of union strength in our main analyses. However, the fact that more employees are union members at a firm does not necessarily mean that such a firm's union is strong. To supplement the proxy validity of our measures, we note the possible consequence of union strength. If a union is a stronger wage negotiator, it should realize higher wage increases for its members. In this spirit, we compute the changes in wage and create a dummy variable ( $H W G)$ to proxy for high wage growth. This variable takes the value of one if the change in wage per employee of a firm exceeds the industry mean in a given year, and zero otherwise. ${ }^{20} \mathrm{We}$ then interact the dummy variable with our main test variable (Union) in Eq. (1). The negative relation between Union and Log(\#Disclosures) or Log(\#Good News Disclosures) would be stronger for firms with higher wage increases. Untabulated results show that the coefficient on this interaction variable is significantly negative in some specifications, supporting our prediction that the negative association between union strength and disclosure frequency, especially for good news, is more prominent when the labor union is more successful in the wage bargaining process.

Most labor unions in Korea are affiliated with at least one of two upper level union associations. They are the Federation of Korean Trade Unions (FKTU, Hankuk Nochong in Korean) and the Korean Confederation of Trade Unions (KCTU, Minjoo Nochong in Korean).

\footnotetext{
${ }^{20}$ We estimate it by dividing the total salary expenses by the total number of employees, which include CEO and other top level managers. As a result, this estimate contains measurement errors to the extent that it does not exactly represent the average wage level of workers who are eligible for union membership.
} 
These associations set the general guidelines for the direction of union activities and assist specific bargaining processes for individual unions. Our sample contains a subset of 1,097 and 274 member firms for FKTU and KCTU, respectively. As most of the unionized firms in our sample are affiliated with one or both of these associations, we conjecture that the previously reported effect of union strength on disclosure is mainly driven by these affiliated unions. ${ }^{21}$ That is, the labor unions that are not affiliated with any of these associations may have unique and different characteristics compared to affiliated unions in terms of its attitudes on firms' policies. Thus, we repeat the analyses in Tables 2,4 , and 5 after excluding these 122 non-affiliated unions. Unreported results show that all the main implications are robust to this change, indicating that our main results presented in previous tables are mainly driven by the firms with associationaffiliated unions.

In sum, the results of various sensitivity tests corroborate our main findings that managers reduce good news disclosure and promote bad news disclosure when their labor unions are stronger, and this tendency is more pronounced during the collective bargaining process.

\section{Conclusions}

Using a large sample of Korean listed firms for which firm-year level unionization rates and the voluntary disclosure frequency data are available, we find that management's overall disclosure frequency is negatively related to the firm's labor union strength. We also report that this tendency for managers to withhold information from strong unions is mainly driven by good news firms. Finally, we find that managers "time" news disclosure by withholding good news during the collective bargaining process and then by releasing it in an abrupt fashion subsequently, and that this tendency is more pronounced for the firms with stronger labor unions.

\footnotetext{
${ }^{21}$ Only $8 \%$ (122 out of 1,371$)$ observations of the unionized firms are not affiliated with any of these associations.
} 
Taken together, we provide evidence that managers tend to hide news, especially when it is good, to preserve their bargaining power against labor when their firms have stronger unions.

This paper provides important implications for managers, employees, investors, and researchers. Our findings on the role of labor unions suggest that employees can be a group that incurs another form of agency costs by distorting corporate activities such as disclosures, thereby exacerbating information asymmetry and return volatility. Employees need to understand that managers can react strategically to their rent-seeking wage demands by exercising discretion on the amount of disclosed information and the timing of its disclosure. Since these distortions in managerial activities create costs, an excessive wage demand can be detrimental to both parties. Investors can get a helpful tip for their portfolio selections by recognizing that given the same cash flows and risks, a firm with a stronger labor union exhibits more unstable stock price movements due to the blocked information flows and intensified information asymmetry. Researchers can learn a valuable insight from our findings when they investigate the dynamics between corporate members and market participants in terms of agency problems and the cost of disclosures.

Like most empirical studies, our research has limitations. Though we attempt to address concerns about the possible weakness in causality between labor union strength and disclosure frequency, and on the endogeneity in disclosure and union strength by adopting change specifications and 2SLS, the main results documented in this paper is not completely free of these concerns. To the extent that the main variables of interest are determined endogenously and the true levels of managerial disclosure activity and union strength are measured with errors by the adopted proxies, and to the extent that our manual news classifications are subjective, the reported results can be spurious. Notwithstanding, we believe that the consistent results from 
various robustness analyses ameliorate these concerns, corroborate the negative relation between labor union strength and disclosure frequency, and confirm managerial disclosure timing. 


\section{References}

Aboody, D. and D. Kasznik, 2000. CEO stock option awards and the timing of corporate voluntary disclosures. Journal of Accounting and Economics 29: 73-100.

Ali, A., S. Klasa, and E. Yeung, 2009. Product market competition and corporate disclosure policy. Working Paper, University of Texas at Dallas.

Antos, J., M. Chandler, and W. Mellow, 1980. Sex differences in union membership. Industrial and Labor Relations Review 33: 162-169.

Baginski, S., J. Hassell, and M. Kimbrough, 2002. The effect of the legal environment on voluntary disclosure: evidence from management earnings forecasts issued in U.S. and Canadian markets. The Accounting Review 77: 25-50.

Ball, R., 2009. Market and political/regulatory perspectives on the recent accounting scandals. Journal of Accounting Research 47: 277-323.

Bhattacharya, S., and J. Ritter, 1983. Innovation and communication: Signaling with partial disclosure. Review of Economic Studies 50: 331-346.

Black, B., and W. Kim, 2012. The effect of board structure on firm value: A multiple identification strategies approach using Korean data. Journal of Financial Economics, 104: 203-226.

Bova, F., 2012. Labor unions and management's incentive to signal a negative outlook. Contemporary Accounting Research, forthcoming.

Bowen, R., L. Ducharme, and D. Shores, 1995. Stakeholders implicit claims and accounting method choice. Journal of Accounting and Economics 20: 225-294.

Brander, J., and J. Eaton, 1984. Product line rivalry. American Economic Review 74: 323-334.

Brennan, N., 1999. Voluntary disclosure of profit forecasts by target companies in takeover bids. Journal of Business Finance and Accounting 26: 883-918.

Bronars, S., and D. Deere, 1994. Unionization and profitability: Evidence of spillover effects. Journal of Political Economy 102: 1281-1287.

Bronars, S., D. Deere, and J. Tracy, 1994. The effects of unions on firm behavior: an empirical analysis using firm-level data. Industrial Relations 33: 426-451.

Busse, J., and T. Green. 2002. Market efficiency in real time. Journal of Financial Economics 65: 415-437.

Chen, H., M. Kacperczyk, and H. Ortiz-Molina. 2010. Do non-financial stakeholders affect the pricing of risky debt? Evidence from unionized workers. Review of Finance, forthcoming.

Chen, H., M. Kacperczyk, and H. Ortiz-Molina. 2011. Labor unions, operating flexibility, and the cost of equity. Journal of Financial and Quantitative Analysis 46: 25-58.

Chen, C., and N. Mohan. 1994. Timing the disclosure of information: Management's view of earnings announcements. Financial Management 23(3): 63-69.

Chyz, J., W. Leung, O. Li, and O. Rui. 2011. Labor unions and tax aggressiveness, available at SSRN: http://papers.ssrn.com/sol3/papers.cfm?abstract id=1498663.

Clarke, R., 1983. Collusion and the incentives for information sharing. Bell Journal of Economics 14: 383-394.

Cullinan, C., and D. Bline, 2003. The effects of labour and accounting choice in Canada. Contemporary Accounting Research 2: 135-51.

Darrough, M., 1993. Disclosure policy and competition: Cournot vs. Bertrand. The Accounting Review 68: 534-561.

DeAngelo, H., and L. DeAngelo, 1991. Union negotiations and corporate policy. Journal of 
Financial Economics 30: 3-43.

DeAngelo, L., 1988. Managerial competition, information cost, and corporate governance: the use of accounting performance measures in proxy contests. Journal of Accounting and Economics 10: 3-37.

Diamond, D., and R. Verrecchia, 1991. Disclosure, liquidity, and the cost of capital. Journal of Finance 46: 1325-59.

Dimitrov, V., and P. Jain. 2011. It's showtime: Do managers report better news before annual shareholder meetings? Journal of Accounting Research 49: 1193-1221.

D'Souza, J., J. Jacob, and K. Ramesh, 2000. The use of accounting flexibility to reduce labor renegotiation costs and manage earnings, Journal of Accounting and Economics 30: 187208.

Dye, R., 2001. An evaluation of "essays on disclosure" and the disclosure literature in accounting. Journal of Accounting and Economics 32: 181-235.

Easley, D., N. Kiefer, M. O'Hara. 1997. One day in the life of a very common stock. Review of Financial Studies 10: 805-835.

Fama, E., and J. MacBeth, 1973. Risk, return, and equilibrium: Empirical tests. Journal of Political Economy 81: 607-636.

Gal-Or, E., 1985. Information sharing in oligopoly. Econometrica 53: 329-343.

Glosten, L. and P. Milgrom. 1985. Bid, ask, and transaction prices in a specialist market with heterogeneously informed traders. Journal of Financial Economics 14: 71-100.

Graham, J., C. Harvey, and S. Rajgopal, 2005. The economic implications of corporate financial reporting. Journal of Accounting and Economics 40: 3-73.

Healy, P. and K. Palepu, 2001. Information asymmetry, corporate disclosure, and capital markets: a review of the empirical disclosure literature. Journal of Accounting and Economics 31: 405-40.

Hilary, G., 2006. Organized labor and information asymmetry in the financial markets. Review of Accounting Studies 11: 525-548.

Hirsch, B., 1980. The determinants of unionization: An analysis of inter-area differences. Industrial and Labor Relations Review 33: 147-161.

Hirsch, B., 1991. Union coverage and profitability among U.S. firms. The Review of Economics and Statistics 73: 69-77.

Hirsch, B., 1992. Firm investment behavior and collective bargaining strategy. Industrial Relations 31: 95-121.

Hutton, A., G. Miller, and D. Skinner. 2003. The role of supplementary statements with management earnings forecasts. Journal of Accounting Research 41: 867-890.

Jensen, M. and W. Meckling, 1976. Theory of the firm: managerial behavior, agency costs and ownership structure. Journal of Financial Economics 3: 305-360.

Kasznik, R. and B. Lev, 1995. To warn or not to warn: management disclosures in the face of an earnings surprise. The Accounting Review 70: 113-34.

Khan, M. and R. Watts, 2009. Estimation and empirical properties of a firm-year measure of accounting conservatism. Journal of Accounting and Economics 48: 132-150.

Klasa, S., W. Maxwell, and H. Ortiz-Molina, 2009. The strategic use of corporate cash holdings in collective bargaining with labor unions. Journal of Financial Economics 92: 421-442.

Kleiner, M., and M. Bouillon. 1988. Providing business information to production workers: Correlates of compensation and profitability. Industrial and Labor Relations Review 41: $605-617$. 
Korea Exchange (KRX). 2005. (Amended) Disclosure Regulation of the Korean stock market.

Korea Stock Exchange (KSE). 2002. Disclosure regulation of the Korean stock market.

Kothari, S., S. Shu, and P. Wysocki, 2009. Do managers withhold bad news? Journal of Accounting Research 47: 241-276.

La Porta, R., F. Lopez-De-Silanes, and A. Shleifer. 2006. What works in securities laws? Journal of Finance 61: 1-32.

LaFond, R., and R. Watts, 2008. The information role of conservatism. The Accounting Review 83: 447-478.

Lang, M., and R. Lundholm, 1993. Cross-sectional determinants of analysts' ratings of corporate disclosures. Journal of Accounting Research 31: 246-271.

Lara, G., J. Manuel, B. Osma, and A. Mora, 2005. The effect of earnings management on the asymmetric timeliness of earnings. Journal of Business Finance and Accounting 32: 691726.

Larcker, D. and T. Rusticus, 2010. On the use of instrumental variables in accounting research. Journal of Accounting and Economics 49: 186-205.

Leap, T., 1991. Collective bargaining and labor relations (2nd ed.). New Jersey: Prentice Hall, Englewood Cliffs.

Lev, B., and S. Penman, 1990. Voluntary forecast disclosures, nondisclosure, and stock prices. Journal of Accounting Research 28: 49-76.

Liberty, S., and J. Zimmerman, 1986. Labor union negotiations and accounting choice. The Accounting Review 61: 692 - 712.

Matsa, D., 2010. Capital structure as a strategic variable: evidence from collective bargaining. Journal of Finance 65: 1197-1232.

Merton, R., 1987. A simple model of capital market equilibrium with incomplete information. Journal of Finance 42: 483-510.

Morck, R., A. Shleifer, and R. Vishny, 1990. Do management objectives drive bad acquisitions? Journal of Finance 45: 31-50.

Nagar, V., D. Nanda, and P. Wysocki, 2003. Discretionary disclosure and stock-based incentives. Journal of Accounting and Economics 34: 283-309.

Petersen, M., 2009. Estimating standard errors in finance panel data sets: comparing approaches. Review of Financial Studies 22: 435-480.

Rock, S., S. Sedo, M. Willenborg. 2000. Analyst following and count-data econometrics. Journal of Accounting and Economics 30: 351-373.

Simunic, D., 1980. The pricing of audit services: theory and evidence. Journal of Accounting Research 18 (1): 161-190.

Skinner, D., 1994. Why firms voluntarily disclose bad news? Journal of Accounting Research 32: $38-61$.

Skinner, D., 1997. Earnings disclosures and stockholder lawsuits. Journal of Accounting and Economics 23: 249-83.

Verrecchia, R., 1990. Information quality and discretionary disclosure. Journal of Accounting and Economics 12: 179-94.

Verrecchia, R., 2001. Essays on disclosure. Journal of Accounting \& Economics 32: 97-180.

Warner, J., R. Watts, and K. Wruck, 1988. Stock prices and top management changes. Journal of Financial Economics 20: 461-493.

Yermack, D., 1997. Good timing: CEO stock option awards and company news announcements. Journal of Finance 52: 449-76. 


\section{Appendix A. Variable definitions}

\begin{tabular}{|c|c|}
\hline Log(\#Disclosures) & The natural logarithm of one plus the number of disclosures \\
\hline $\begin{array}{l}\log (\# \text { Good News } \\
\text { Disclosures })\end{array}$ & $\begin{array}{l}\text { The natural logarithm of one plus the number of good news disclosures, either for a } \\
\text { given year or month }\end{array}$ \\
\hline $\begin{array}{l}\text { Log(\#Bad News } \\
\text { Disclosures) }\end{array}$ & $\begin{array}{l}\text { The natural logarithm of one plus the number of bad news disclosures, either for a } \\
\text { given year or month }\end{array}$ \\
\hline Unionization rate & The proportion of the number of union members to total number of employees \\
\hline Qdum & $\begin{array}{l}\text { An indicator variable which equals one if the individual news is disclosed in the } \\
\text { second quarter of year } t \text {, and zero otherwise. }\end{array}$ \\
\hline Offer & $\begin{array}{l}\text { An indicator variable which equals one if a firm issues a new equity during a year, } \\
\text { and zero otherwise. }\end{array}$ \\
\hline RET & $\begin{array}{l}\text { Contemporaneous buy-and-hold annual returns for the one year period starting } \\
\text { from the fourth month after fiscal year-end t- } 1\end{array}$ \\
\hline Loss & $\begin{array}{l}\text { An indicator variable which equals one if a firm reports negative net income, and } \\
\text { zero otherwise }\end{array}$ \\
\hline HHI & $\begin{array}{l}\text { The Herfindahl-Hirschman index based on sales, computed as the sum of squared } \\
\text { market shares within the same industry in year } t\end{array}$ \\
\hline OpCycle & $\begin{array}{l}\text { Operating cycle, measured as the average receivables divided by sales plus the } \\
\text { average inventory divided by the cost of goods sold }\end{array}$ \\
\hline BigAudit & $\begin{array}{l}\text { Big auditor dummy, which equals one if the firm is audited by PWC, KPMG, } \\
\text { Deloitte, or Ernst and Young (or their affiliated Korean auditing firms), and zero } \\
\text { otherwise }\end{array}$ \\
\hline Size & The natural logarithm of fiscal year-end market capitalization \\
\hline $\mathrm{BM}$ & Book value of equity divided by market value of equity \\
\hline Log(\#Analysts) & The natural logarithm of one plus the number of analysts following the firm \\
\hline Log(\#Owners) & The natural logarithm of the number of shareholders \\
\hline LEV & Leverage, measured as the total debt divided by market value of equity \\
\hline ROA & Return on assets, defined as the net income divided by total assets \\
\hline Chaebol & $\begin{array}{l}\text { A dummy variable, which equals one if the firm belongs to Chaebol, and zero } \\
\text { otherwise. Korean Fair Trade Commission (KFTC) identifies every group of } \\
\text { companies of which more than } 30 \% \text { of the shares are owned by controlling } \\
\text { shareholders and their affiliated companies. A firm belongs to Chaebol if it is one } \\
\text { of these affiliated companies. }\end{array}$ \\
\hline ForOwn & $\begin{array}{l}\text { Foreign ownership, measured as the ratio of the number of shares owned by } \\
\text { foreign investors to the number of total shares outstanding }\end{array}$ \\
\hline Female & The ratio of the number of female employees to the number of total employees \\
\hline HWG & $\begin{array}{l}\text { High wage growth dummy, which equals one if the change in the average wage per } \\
\text { employee exceeds industry mean in year } t \text {, and zero otherwise }\end{array}$ \\
\hline Association & $\begin{array}{l}\text { Affiliation to labor union associations, which equals one if a firm's union belongs } \\
\text { to one (or both) of the two union associations, and zero otherwise }\end{array}$ \\
\hline
\end{tabular}




\section{Appendix B. News classification criteria and examples of news}

\section{News classification criteria}

The corporate disclosure data used in this study are hand-collected from the Korea Investor's Network for Disclosure (KIND) System. The corporate information subject to Reg FD in Korea includes "Future Business \& Management Plan", "Forecasts of Sales, Operating Income, Continuing Business Income Before Tax (or Ordinary Income), or Net Income", "Preannouncement of Sales, Operating Income, Continuing Business Income Before Tax (or Ordinary Income), or Net Income" and "Major Managerial Issues" (KSE 2002; KRX 2005). To assess the characteristics of disclosure information, we follow several different methodologies used in prior literature. First, we determine whether earnings forecasts or preannouncements are positive or negative by comparing them with analysts' forecasts. If they exceed the most recently announced financial analysts' consensus forecasts before the disclosure, they are classified as positive news. Otherwise, they are classified as negative. If there is no analyst following, they are compared with prior month's, quarter's or year's earnings performance. However, in some situations, they may not be classified into only one category. For example, a quarterly earnings forecast may be positive when compared with a prior quarter's performance but negative if compared with the same quarter's performance in the previous year. In such a case, it is classified as neutral. On the other hand, we characterize qualitative corporate information such as "Future Business \& Management Plan" and "Major Managerial Issues" by judging the sentiment or tone of disclosures (Busse and Green, 2002). This classification criterion may appear subjective but the sentiments and tones of disclosure information are quite straightforward (as shown in the examples below). In many cases, "Future Business \& Management Plans" and "Major Managerial Issues" deliver positive news such as new businesses, new markets, new products, new technologies, strategic alliances with other domestic or foreign companies, or a dividend distribution. Negative disclosure usually contains news about the cancellation of contracts, discontinuation of unprofitable business, or withdrawal from foreign markets. If it is not clear whether it has a positive or negative effect on firm value, it is classified as neutral. For example, the news about the change in pricing policy is classified as neutral unless it accompanies an expected positive or negative effect on firms' business prospects. Companies sometimes disclose both earnings news and business plans or managerial issues together. In such cases, the disclosure is classified as positive or negative when both types of news are consistently characterized. Otherwise, it is classified as neutral.

\section{Examples of news}

1. "Forecasts of Sales, Operating Income, Continuing Business Income Before Tax (or Ordinary Income), or Net Income" or "Preannouncement of Sales, Operating Income, Continuing Business Income Before Tax (or Ordinary Income), or Net Income"

\section{Good news:}

SK Co., Ltd. disclosed the following news on January 27, 2005:

"Sales, Operating Income, Ordinary Income, and Net Income for the $4^{\text {th }}$ quarter of 2005 are 4,962, 452, 832, and 612 billion Korean won, respectively, and all these numbers have increased both from the $3^{\text {rd }}$ quarter of 2005 and the $4^{\text {th }}$ quarter of 2004 (detailed past period numbers and ratios of changes included)." 
Bad news:

Samsung Electronics Co., Ltd. disclosed the following news on April 13, 2007:

"Sales, Operating Income, Ordinary Income, and Net Income for the $1^{\text {st }}$ quarter of 2007 are 144, 12, 18, and 16 billion Korean won, respectively, and all these numbers have decreased from the $4^{\text {th }}$ quarter of 2006 . They also have decreased from the $1^{\text {st }}$ quarter of 2006 except Sales, which has increased (detailed past period numbers and ratios of changes included)."

\section{Neutral news:}

Korean Air Co., Ltd. disclosed the following news on February 1, 2006:

"Sales in the passenger division for December 2005 were 3,912 million Korean won, which have increased from November 2005 but decreased from December 2004. Sales in the cargo division for December 2005 were 659 million Korean won, which have decreased both from November 2005 and December 2004. The capacity utilization rate in the passenger division for December 2005 was $68.8 \%$, which has increased both from November 2005 and December 2004, while the capacity utilization rate in the cargo division for December 2005 was $75.6 \%$, which has decreased both from November 2005 and December 2004 (detailed past period numbers and ratios of changes included)."

\section{2. "Future Business \& Management Plan" or "Major Managerial Issues"}

Good news:

KT Inc. disclosed the following news on January 5, 2005:

"We signed MOU on the extension of strategic alliances with Microsoft. Major contents include: 1) Establishing an R\&BD (Research \& Business Development) Center under a co-investment scheme, 2) Building this R\&BD Center in Korea, 3) Establishing a matching fund to utilize the external contents, technologies, and human resources of this R\&BD Center, and 4) Setting up a human resource exchange program that includes seminars, educations, and exchanges of personnel in various business areas."

\section{Bad news:}

LS Co., Ltd. disclosed the following news on January 4, 2005:

"At the preliminary decision made in June 2004, the Chinese Ministry of Commerce levied 7\% of anti-dumping tariff on our company for our exported optical fibers. The Chinese Ministry of Commerce has conducted additional investigations since then, and sent the formal letter of final decision to our company today. Based on No. 25 of AntiDumping Act of the People's Republic of China, the final decision confirmed the $7 \%$ tariff set at the preliminary decision."

\section{Neutral news:}

Korea Gas Corporation disclosed the following news on June 29, 2006:

"The wholesale prices of natural gas sold to households, industries, and power plants have increased effective on 00:00 a.m. July 1, 2006. This adjustment is due to the increase of oil price in the market (detailed current and adjusted wholesale prices and ratios of changes included)." 
Figure 1. Monthly average of disclosure frequency

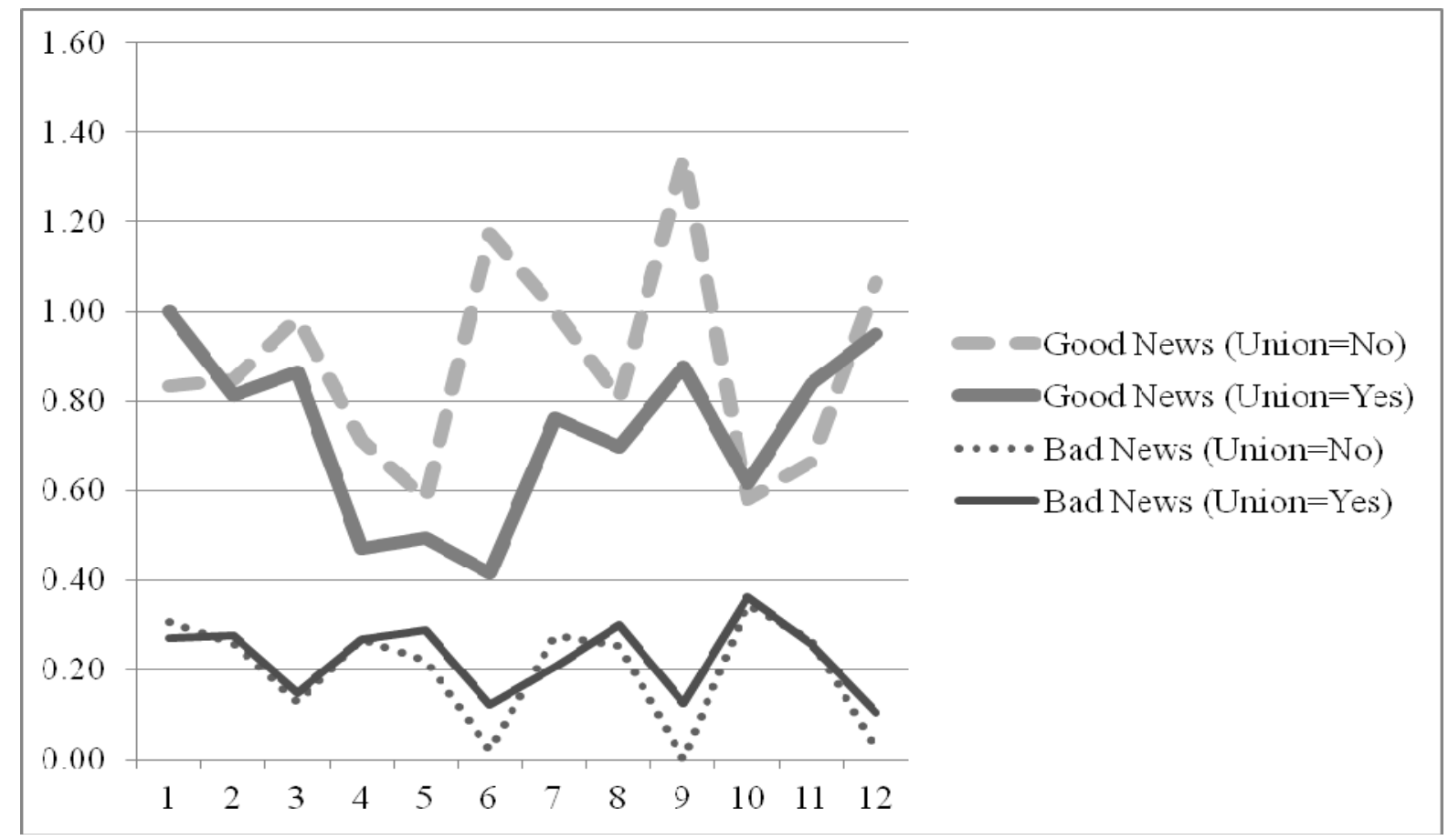

Notes:

This figure illustrates the monthly pattern of disclosure frequency for good news in Panel A and for bad news in Panel B. We count the number of good or bad news disclosed in each month from January to December for all the firms in the sample and then plot the monthly frequency for unionized firms and non-unionized firms separately. Panel A shows that good news disclosure decreases significantly during the second calendar quarter (i.e., April to June) and rebounds afterwards for both unionized and non-unionized firms, and that this pattern is more prominent for unionized firms. Panel B shows that bad news disclosure does not have a distinct pattern for both unionized and non-unionized firms, though the tendency of disclosing bad news in the second calendar quarter seems to be slightly stronger for unionized firms. 
Figure 2. Monthly market-adjusted stock returns

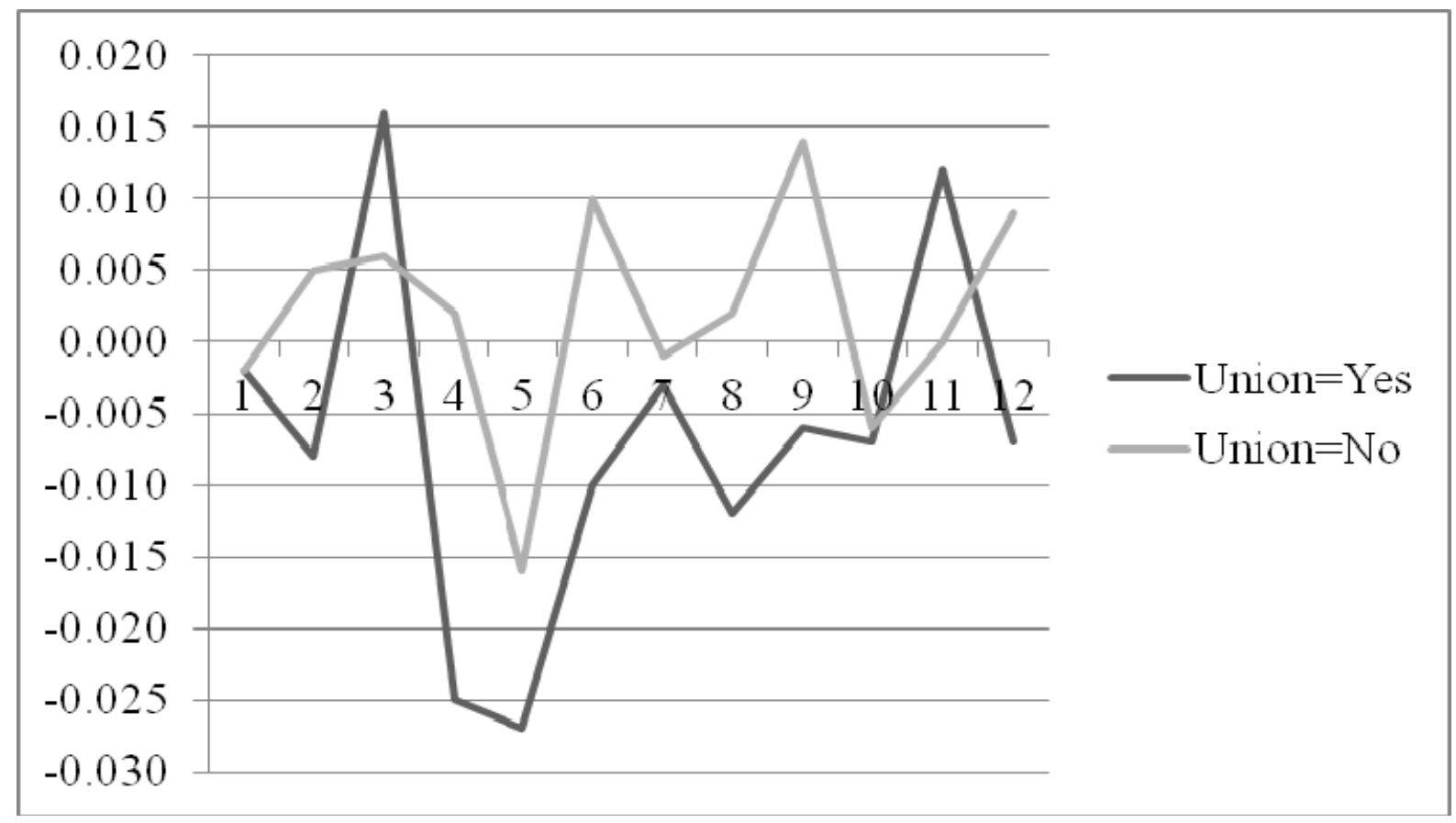

Notes:

This figure illustrates the monthly pattern of market-adjusted abnormal stock returns for unionized and nonunionized firms. We regress each firm's monthly return on the value-weighted monthly market return and estimate the residual to compute the abnormal return. We average these abnormal monthly returns by each month from January to December and plot them for unionized and non-unionized firms separately. Monthly abnormal returns decrease significantly during the second quarter (i.e., April to June) and rebound afterwards for both unionized and non-unionized firms, and this pattern is more pronounced for unionized firms. 
Table 1. Descriptive statistics

Panel A. Summary statistics

\begin{tabular}{ccccccc}
\hline Variables & $\mathrm{N}$ & Mean & Std. dev. & 25th Pctl. & Median & 75th Pctl. \\
\hline Union Existence & 2,084 & 0.716 & 0.451 & 0.000 & 1.000 & 1.000 \\
Unionization Rate & 2,084 & 0.343 & 0.281 & 0.000 & 0.381 & 0.592 \\
\#Disclosures & 2,084 & 2.337 & 3.484 & 0.000 & 1.000 & 4.000 \\
\#Good News & 2,084 & 1.223 & 2.108 & 0.000 & 0.000 & 2.000 \\
\#Bad News & 2,084 & 0.385 & 1.036 & 0.000 & 0.000 & 0.000 \\
Log(\#Owners) & 2,084 & 8.096 & 1.165 & 7.270 & 7.913 & 8.733 \\
Offer & 2,084 & 0.096 & 0.295 & 0.000 & 0.000 & 0.000 \\
RET & 2,084 & 0.335 & 1.201 & -0.127 & 0.110 & 0.510 \\
Loss & 2,084 & 0.180 & 0.385 & 0.000 & 0.000 & 0.000 \\
HHI & 2,084 & 0.104 & 0.053 & 0.080 & 0.085 & 0.111 \\
OpCycle & 2,084 & 0.385 & 0.209 & 0.250 & 0.330 & 0.453 \\
BigAudit & 2,084 & 0.581 & 0.494 & 0.000 & 1.000 & 1.000 \\
Size & 2,084 & 25.156 & 1.678 & 23.968 & 24.831 & 26.031 \\
BM & 2,084 & 1.846 & 1.400 & 0.834 & 1.480 & 2.425 \\
Log(\#Analysts) & 2,084 & 2.252 & 2.414 & 0.000 & 1.242 & 4.644 \\
LEV & 2,084 & 1.085 & 1.624 & 0.126 & 0.509 & 1.267 \\
ROA & 2,084 & 0.030 & 0.086 & 0.009 & 0.039 & 0.071 \\
Chaebol & 2,084 & 0.188 & 0.391 & 0.000 & 0.000 & 0.000 \\
ForOwn & 2,084 & 0.100 & 0.149 & 0.002 & 0.021 & 0.149 \\
\hline
\end{tabular}




\section{Table 1 (continued)}

Panel B. High vs. low union samples

\begin{tabular}{lccccc}
\hline \multirow{2}{*}{ Variables } & \multicolumn{2}{c}{ High Unionization } & \multicolumn{2}{c}{ Low Unionization } & Difference \\
\cline { 2 - 6 } & Mean & SD & Mean & SD & p-value \\
\hline Unionization Rate & 0.595 & 0.123 & 0.091 & 0.127 & $<0.01$ \\
\#Disclosures & 1.844 & 3.328 & 2.349 & 3.064 & $<0.01$ \\
\#Good News & 1.099 & 2.049 & 1.347 & 2.160 & $<0.01$ \\
\#Bad News & 0.436 & 1.175 & 0.335 & 0.874 & 0.03 \\
BigAudit & 0.588 & 0.492 & 0.573 & 0.495 & 0.49 \\
Size & 25.353 & 1.759 & 24.958 & 1.570 & $<0.01$ \\
BM & 1.950 & 1.492 & 1.742 & 1.294 & $<0.01$ \\
Log(\#Analysts) & 2.416 & 2.498 & 2.088 & 2.316 & $<0.01$ \\
LEV & 1.249 & 1.810 & 0.919 & 1.394 & $<0.01$ \\
ROA & 0.031 & 0.079 & 0.028 & 0.092 & 0.47 \\
Chaebol & 0.234 & 0.423 & 0.141 & 0.349 & $<0.01$ \\
HHI & 0.102 & 0.064 & 0.105 & 0.040 & 0.18 \\
\hline
\end{tabular}

Notes:

This table presents the descriptive statistics for the main variables. Panel A describes the summary statistics of the variables, and Panel B compares simple statistics of the key variables across high and low unionization subsamples. The firm-year observations are classified into the High (Low) Unionization subsample if its unionization rate falls above (below) the sample median. All variables are defined in Appendix A. 
Table 2. The effect of union strength on disclosure frequency

\begin{tabular}{|c|c|c|c|c|}
\hline \multirow[t]{2}{*}{ Dep. Var $=$} & \multicolumn{2}{|c|}{$\frac{\log (\# \text { Disclosures) }}{\text { OLS }}$} & \multicolumn{2}{|c|}{$\frac{\text { \#Disclosures }}{\text { Negative Binomial }}$} \\
\hline & (1) & (2) & (3) & (4) \\
\hline \multirow[t]{2}{*}{ Union $=$} & Union & Unionization & Union & Unionization \\
\hline & Existence & Rate & Existence & Rate \\
\hline \multirow[t]{2}{*}{ Intercept } & $-3.492 * * *$ & $-3.246 * * *$ & $-4.116 * * *$ & $-3.624 * * *$ \\
\hline & $(<0.01)$ & $(<0.01)$ & $(<0.01)$ & $(<0.01)$ \\
\hline \multirow[t]{2}{*}{ Union } & $-0.180 * * *$ & $-0.197 * * *$ & $-0.257 * * *$ & $-0.210 *$ \\
\hline & $(<0.01)$ & $(<0.01)$ & $(<0.01)$ & $(0.06)$ \\
\hline \multirow{2}{*}{ Log(\#Owners) } & $0.205^{* * *}$ & $0.208 * * *$ & $0.290 * * *$ & $0.295 * * *$ \\
\hline & $(<0.01)$ & $(<0.01)$ & $(<0.01)$ & $(<0.01)$ \\
\hline \multirow[t]{2}{*}{ Offer } & $0.152 * *$ & $0.162 * * *$ & $0.369^{* * *}$ & $0.385^{* * *}$ \\
\hline & $(0.01)$ & $(<0.01)$ & $(<0.01)$ & $(<0.01)$ \\
\hline \multirow[t]{2}{*}{ RET } & 0.007 & 0.006 & 0.030 & 0.030 \\
\hline & $(0.53)$ & $(0.54)$ & $(0.26)$ & $(0.26)$ \\
\hline \multirow[t]{2}{*}{ Loss } & -0.071 & -0.059 & -0.069 & -0.048 \\
\hline & $(0.18)$ & $(0.27)$ & $(0.52)$ & $(0.66)$ \\
\hline \multirow[t]{2}{*}{ HHI } & 0.884 & 0.953 & 1.116 & 1.186 \\
\hline & $(0.33)$ & $(0.29)$ & $(0.53)$ & $(0.51)$ \\
\hline \multirow[t]{2}{*}{ OperCycle } & 0.013 & 0.008 & 0.104 & 0.103 \\
\hline & $(0.89)$ & $(0.93)$ & $(0.59)$ & $(0.60)$ \\
\hline \multirow[t]{2}{*}{ BigAudit } & $0.056^{*}$ & $0.059 *$ & $0.167 * * *$ & $0.175^{* * *}$ \\
\hline & $(0.09)$ & $(0.07)$ & $(0.01)$ & $(<0.01)$ \\
\hline \multirow[t]{2}{*}{ Size } & $0.081 * * *$ & $0.068 * * *$ & 0.053 & 0.030 \\
\hline & $(<0.01)$ & $(<0.01)$ & $(0.22)$ & $(0.49)$ \\
\hline \multirow[t]{2}{*}{$\mathrm{BM}$} & $-0.060 * * *$ & $-0.065 * * *$ & $-0.151 * * *$ & $-0.157 * * *$ \\
\hline & $(<0.01)$ & $(<0.01)$ & $(<0.01)$ & $(<0.01)$ \\
\hline \multirow[t]{2}{*}{ Log(\#Analysts) } & $0.032 * * *$ & $0.036 * * *$ & $0.093 * * *$ & $0.099 * * *$ \\
\hline & $(<0.01)$ & $(<0.01)$ & $(<0.01)$ & $(<0.01)$ \\
\hline \multirow[t]{2}{*}{ LEV } & 0.013 & 0.011 & 0.030 & 0.024 \\
\hline & $(0.24)$ & $(0.32)$ & $(0.20)$ & $(0.30)$ \\
\hline \multirow[t]{2}{*}{ ROA } & -0.188 & -0.138 & -0.280 & -0.183 \\
\hline & $(0.49)$ & $(0.61)$ & $(0.54)$ & $(0.69)$ \\
\hline \multirow[t]{2}{*}{ Chaebol } & $0.138 * * *$ & $0.140 * * *$ & 0.059 & 0.063 \\
\hline & $(<0.01)$ & $(<0.01)$ & $(0.53)$ & $(0.50)$ \\
\hline \multirow[t]{2}{*}{ ForOwn } & 0.091 & 0.080 & 0.327 & 0.332 \\
\hline & $(0.54)$ & $(0.59)$ & $(0.20)$ & $(0.19)$ \\
\hline Year Fixed Effects & Yes & Yes & Yes & Yes \\
\hline Industry Fixed Effects & Yes & Yes & Yes & Yes \\
\hline Observations & 2,084 & 2,084 & 2,084 & 2,084 \\
\hline Adj.R $\mathrm{R}^{2} /$ Log Likelihood & 0.388 & 0.384 & $1,721.92$ & $1,716.93$ \\
\hline
\end{tabular}




\section{Notes:}

This table presents the results of regressing disclosure frequency on firm union strength with control variables. Columns (1) and (2) are based on the OLS regression estimation using the natural logarithm of disclosure frequency (plus one) as a dependent variable. Columns (3) and (4) are based on the negative binomial regression estimation in which the raw values of disclosure frequency are used as dependent variables. Regressions include year and industry fixed effects. Standard errors are heteroskedasticity and serial correlation robust, clustered at the firm level. Numbers in parentheses indicate p-values. ***,**, and * denote the statistical significance at the 1,5 and $10 \%$ levels, respectively (two tailed). All variables are defined in Appendix A. 
Table 3. The effect of union strength on the asymmetric disclosure using firm level classification

Panel A. High versus low earnings surprise

\begin{tabular}{|c|c|c|c|c|}
\hline \multirow[t]{2}{*}{ Union $=$} & \multicolumn{2}{|c|}{ Union Existence } & \multicolumn{2}{|c|}{ Unionization Rate } \\
\hline & $\begin{array}{c}(1) \\
\text { Good News }\end{array}$ & $\begin{array}{l}\text { (2) } \\
\text { Others }\end{array}$ & $\begin{array}{l}\text { (3) } \\
\text { Good News }\end{array}$ & $\begin{array}{l}\text { (4) } \\
\text { Others }\end{array}$ \\
\hline Union & $\begin{array}{l}-0.249 * * * \\
(<0.01)\end{array}$ & $\begin{array}{l}-0.203^{*} \\
(0.05)\end{array}$ & $\begin{array}{l}-0.199 \\
(0.11)\end{array}$ & $\begin{array}{l}-0.166 \\
(0.27)\end{array}$ \\
\hline Intercept / Control Variables & Yes & Yes & Yes & Yes \\
\hline Year Fixed Effects & Yes & Yes & Yes & Yes \\
\hline Industry Fixed Effects & Yes & Yes & Yes & Yes \\
\hline Observations & 451 & 768 & 451 & 768 \\
\hline $\operatorname{Adj} . R^{2}$ & 0.474 & 0.356 & 0.470 & 0.347 \\
\hline $\begin{array}{l}p \text {-value for UNION }(1)=(2) \\
p \text {-value for UNION }(3)=(4)\end{array}$ & \multicolumn{2}{|c|}{0.71} & \multicolumn{2}{|c|}{0.86} \\
\hline
\end{tabular}

Panel B. High versus low sales growth

\begin{tabular}{|c|c|c|c|c|}
\hline \multirow[t]{3}{*}{ Union $=$} & \multicolumn{2}{|c|}{ Union Existence } & \multicolumn{2}{|c|}{$\underline{\text { Unionization Rate }}$} \\
\hline & (1) & $(2)$ & (3) & (4) \\
\hline & Good News & Others & Good News & Others \\
\hline Union & $\begin{array}{l}-0.237 * * * \\
(<0.01)\end{array}$ & $\begin{array}{l}-0.126^{* *} \\
(0.01)\end{array}$ & $\begin{array}{l}-0.225^{* *} \\
(0.02)\end{array}$ & $\begin{array}{l}-0.170^{* *} \\
(0.05)\end{array}$ \\
\hline Intercept / Control Variables & Yes & Yes & Yes & Yes \\
\hline Year Fixed Effects & Yes & Yes & Yes & Yes \\
\hline Industry Fixed Effects & Yes & Yes & Yes & Yes \\
\hline Observations & 1,044 & 1,040 & 1,044 & 1,040 \\
\hline $\operatorname{Adj} . \mathrm{R}^{2}$ & 0.384 & 0.373 & 0.377 & 0.372 \\
\hline$p$-value for UNION (1)=(2) & \multirow{2}{*}{\multicolumn{2}{|c|}{0.08}} & & \\
\hline$p$-value for UNION (3)=(4) & & & \multicolumn{2}{|c|}{0.64} \\
\hline
\end{tabular}




\section{Table 3 (continued)}

Panel C. High versus low dividend changes

\begin{tabular}{|c|c|c|c|c|}
\hline \multirow[t]{2}{*}{ Union $=$} & \multicolumn{2}{|c|}{ Union Existence } & \multicolumn{2}{|c|}{$\underline{\text { Unionization Rate }}$} \\
\hline & $\begin{array}{c}\text { (1) } \\
\text { Good News }\end{array}$ & $\begin{array}{l}(2) \\
\text { Others }\end{array}$ & $\begin{array}{l}\text { (3) } \\
\text { Good News }\end{array}$ & $\begin{array}{c}\text { (4) } \\
\text { Others }\end{array}$ \\
\hline Union & $\begin{array}{l}-0.209 * * * \\
(<0.01)\end{array}$ & $\begin{array}{l}-0.140^{* * *} \\
(<0.01)\end{array}$ & $\begin{array}{l}-0.304 * * * \\
(<0.01)\end{array}$ & $\begin{array}{l}-0.103 \\
(0.24)\end{array}$ \\
\hline Intercept / Control Variables & Yes & Yes & Yes & Yes \\
\hline Year Fixed Effects & Yes & Yes & Yes & Yes \\
\hline Industry Fixed Effects & Yes & Yes & Yes & Yes \\
\hline Observations & 1,000 & 1,084 & 1,000 & 1,084 \\
\hline $\operatorname{Adj} . \mathrm{R}^{2}$ & 0.413 & 0.388 & 0.411 & 0.385 \\
\hline$p$-value for UNION $(1)=(2)$ & \multirow{2}{*}{\multicolumn{2}{|c|}{0.12}} & \multirow{2}{*}{\multicolumn{2}{|c|}{$<0.01$}} \\
\hline$p$-value for UNION (3) $=(4)$ & & & & \\
\hline
\end{tabular}

\section{Notes:}

This table presents the OLS estimation results obtained by regressing the natural logarithm of disclosure frequency (plus one) on firm union strength with control variables. In Panel A, we define "Good News" firms if earnings surprises exceed 1\% of actual earnings. In Panel B, we define "Good News" firms if the sales growth ratio is greater than the sample median. In Panel C, we define "Good News" firms if dividend changes are greater than zero. The remaining firms are defined as "Others" in each panel. Regressions include intercept, control variables, year and industry fixed effects. Numbers in parentheses indicate p-values. Standard errors are heteroskedasticity and serial correlation robust, clustered at the firm level. ***,**, and $*$ denote the statistical significance at the 1,5 and $10 \%$ levels, respectively (two tailed). All variables are defined in Appendix A. 
Table 4. The effect of union strength on asymmetric disclosure using disclosure level classification

Panel A. Number of firms disclosing good news or bad news

\begin{tabular}{ccccccc}
\hline & \multicolumn{2}{c}{ Total } & \multicolumn{2}{c}{ Good News } & \multicolumn{2}{c}{ Bad News } \\
Year & \#Ferage & Average & Average \\
\#Disclosure & \#Firms & \#Disclosure & \#Firms & \begin{tabular}{c} 
\#Disclosure \\
\hline 2003
\end{tabular} \\
2004 & 410 & 2.621 & 206 & 1.790 & 64 & 0.225 \\
2005 & 403 & 2.080 & 193 & 1.572 & 42 & 0.245 \\
2006 & 415 & 2.028 & 178 & 1.097 & 79 & 0.578 \\
2007 & 421 & 2.241 & 173 & 1.073 & 99 & 0.625 \\
\hline Total & 2,084 & 2.127 & 188 & 1.197 & 107 & 0.658 \\
\hline
\end{tabular}


Table 4 (continued)

Panel B. Regression results

\begin{tabular}{|c|c|c|c|c|}
\hline \multirow[t]{2}{*}{ Dep. Var $=$} & \multicolumn{2}{|c|}{$\frac{\log (\# \text { Disclosures) }}{\text { OLS }}$} & \multicolumn{2}{|c|}{ Negative $\frac{\text { \# Disclosures }}{\text { Binomial Regressions }}$} \\
\hline & (1) & (2) & (3) & (4) \\
\hline News type $=$ & Good news & Bad news & Good news & Bad news \\
\hline Intercept & $\begin{array}{l}-2.228^{* * *} \\
(<0.01)\end{array}$ & $\begin{array}{l}-0.701 \\
(0.10)\end{array}$ & $\begin{array}{l}-4.701 * * \\
(0.01)\end{array}$ & $\begin{array}{l}-28.071 * * * \\
(<0.01)\end{array}$ \\
\hline Union & $\begin{array}{l}-0.178 * * * \\
(<0.01)\end{array}$ & $\begin{array}{r}0.009 \\
(0.80)\end{array}$ & $\begin{array}{l}-0.441 * * * \\
(<0.01)\end{array}$ & $\begin{array}{r}0.172 \\
(0.37)\end{array}$ \\
\hline Log(\#Owners) & $\begin{array}{l}0.157 * * * \\
(<0.01)\end{array}$ & $\begin{array}{l}0.072 * * * \\
(<0.01)\end{array}$ & $\begin{array}{l}0.359^{* * *} \\
(<0.01)\end{array}$ & $\begin{array}{l}0.255^{* * *} \\
(<0.01)\end{array}$ \\
\hline Offer & $\begin{array}{r}0.053 \\
(0.29)\end{array}$ & $\begin{array}{r}0.011 \\
(0.66)\end{array}$ & $\begin{array}{l}0.238^{* *} \\
(0.03)\end{array}$ & $\begin{array}{r}0.064 \\
(0.74)\end{array}$ \\
\hline RET & $\begin{array}{l}-0.008 \\
(0.43)\end{array}$ & $\begin{array}{l}-0.016^{*} \\
(0.06)\end{array}$ & $\begin{array}{l}-0.033 \\
(0.39)\end{array}$ & $\begin{array}{l}-0.100 \\
(0.15)\end{array}$ \\
\hline Loss & $\begin{array}{l}-0.021 \\
(0.64)\end{array}$ & $\begin{array}{r}0.030 \\
(0.31)\end{array}$ & $\begin{array}{l}-0.022 \\
(0.86)\end{array}$ & $\begin{array}{c}0.256 \\
(0.15)\end{array}$ \\
\hline HHI & $\begin{array}{l}0.416 \\
(0.57)\end{array}$ & $\begin{array}{l}-0.982^{*} \\
(0.05)\end{array}$ & $\begin{array}{l}1.292 \\
(0.53)\end{array}$ & $\begin{array}{r}0.360 \\
(0.91)\end{array}$ \\
\hline OperCycle & $\begin{array}{r}0.019 \\
(0.82)\end{array}$ & $\begin{array}{l}-0.044 \\
(0.26)\end{array}$ & $\begin{array}{c}0.223 \\
(0.30)\end{array}$ & $\begin{array}{l}-0.149 \\
(0.71)\end{array}$ \\
\hline BigAudit & $\begin{array}{l}-0.001 \\
(0.97)\end{array}$ & $\begin{array}{l}0.042 * * \\
(0.01)\end{array}$ & $\begin{array}{r}0.015 \\
(0.84)\end{array}$ & $\begin{array}{l}0.326^{* *} \\
(0.01)\end{array}$ \\
\hline Size & $\begin{array}{l}0.062 * * * \\
(<0.01)\end{array}$ & $\begin{array}{l}0.036^{* * *} \\
(<0.01)\end{array}$ & $\begin{array}{c}0.068 \\
(0.17)\end{array}$ & $\begin{array}{r}0.077 \\
(0.30)\end{array}$ \\
\hline BM & $\begin{array}{l}-0.046^{* * *} \\
(<0.01)\end{array}$ & $\begin{array}{l}0.022^{* * *} \\
(<0.01)\end{array}$ & $\begin{array}{l}-0.197 * * * \\
(<0.01)\end{array}$ & $\begin{array}{c}0.108 \\
(0.14)\end{array}$ \\
\hline Log(\#Analysts) & $\begin{array}{r}0.005 \\
(0.60)\end{array}$ & $\begin{array}{l}0.041^{* * * *} \\
(<0.01)\end{array}$ & $\begin{array}{r}0.027 \\
(0.23)\end{array}$ & $\begin{array}{l}0.331^{* * *} \\
(<0.01)\end{array}$ \\
\hline LEV & $\begin{array}{c}0.012 \\
(0.17)\end{array}$ & $\begin{array}{c}0.002 \\
(0.62)\end{array}$ & $\begin{array}{c}0.041 \\
(0.15)\end{array}$ & $\begin{array}{l}-0.070 \\
(0.29)\end{array}$ \\
\hline ROA & $\begin{array}{l}0.481 * * \\
(0.04)\end{array}$ & $\begin{array}{r}0.111 \\
(0.34)\end{array}$ & $\begin{array}{l}1.037^{*} \\
(0.05)\end{array}$ & $\begin{array}{c}0.306 \\
(0.76)\end{array}$ \\
\hline Chaebol & $\begin{array}{r}0.040 \\
(0.37)\end{array}$ & $\begin{array}{c}0.024 \\
(0.44)\end{array}$ & $\begin{array}{c}0.046 \\
(0.66)\end{array}$ & $\begin{array}{l}-0.190 \\
(0.18)\end{array}$ \\
\hline ForOwn & $\begin{array}{l}-0.015 \\
(0.90)\end{array}$ & $\begin{array}{c}0.080 \\
(0.38)\end{array}$ & $\begin{array}{l}-0.154 \\
(0.60)\end{array}$ & $\begin{array}{l}0.101 \\
(0.79)\end{array}$ \\
\hline Year Fixed Effects & Yes & Yes & Yes & Yes \\
\hline Industry Fixed Effects & Yes & Yes & Yes & Yes \\
\hline Observations & 2,084 & 2,084 & 2,084 & 2,084 \\
\hline Adjusted / Pseudo R ${ }^{2}$ & 0.310 & 0.321 & 0.112 & 0.112 \\
\hline
\end{tabular}




\section{Notes:}

This table presents the impact of union strength on good and bad news disclosures. In this table, we read all disclosures to identify good, bad, or neutral news using the criteria introduced in Appendix B. Panel A shows the proportions of good news disclosures relative to total disclosures. Panel B is based on the logistic regression estimation using an indicator for at least one good news disclosure in a given year for columns (1) and (2), and using an indicator for at least one bad news disclosure in a given year for columns (3) and (4) as the dependent variable. Panel $\mathrm{C}$ is based on the negative binomial regression estimation in which the raw values of good news or bad news disclosure frequency are used as the dependent variable. Regressions include year and industry fixed effects. Standard errors are heteroskedasticity and serial correlation robust, clustered at the firm level. Numbers in parentheses indicate $\mathrm{p}$-values. $* * * * *$, and $*$ denote the statistical significance at the 1,5 and $10 \%$ levels, respectively (two tailed). All variables are defined in Appendix A. 
Table 5. Labor union strength and managers' timing asymmetric disclosure

\begin{tabular}{|c|c|c|c|c|}
\hline \multirow[t]{2}{*}{ Dep. Var $=$} & \multicolumn{2}{|c|}{$\begin{array}{c}\text { \#Good News Disclosures } \\
\text { Negative Binomial Regressions }\end{array}$} & \multicolumn{2}{|c|}{$\begin{array}{c}\text { \#Bad News Disclosures } \\
\text { Negative Binomial Regressions }\end{array}$} \\
\hline & (1) & (2) & (3) & (4) \\
\hline \multirow[t]{2}{*}{ Intercept } & -1.035 & $-1.945^{*}$ & -2.012 & -3.178 \\
\hline & $(0.31)$ & $(0.05)$ & $(0.25)$ & $(0.19)$ \\
\hline \multirow[t]{2}{*}{ Union } & $-0.289 * * *$ & $-0.220 * *$ & 0.092 & 0.104 \\
\hline & $(<0.01)$ & $(0.02)$ & $(0.40)$ & $(0.49)$ \\
\hline Union*Qdum & & $\begin{array}{l}-0.425^{* *} \\
(0.01)\end{array}$ & & $\begin{array}{r}0.109 \\
(0.66)\end{array}$ \\
\hline Qdum & & $\begin{array}{l}-0.116 \\
(0.12)\end{array}$ & & $\begin{array}{l}-0.088 \\
(0.48)\end{array}$ \\
\hline \multirow[t]{2}{*}{ Log(\#Owners) } & 0.023 & 0.026 & -0.016 & -0.017 \\
\hline & $\begin{array}{c}(0.48) \\
0.006\end{array}$ & $\begin{array}{r}(0.42) \\
0.002\end{array}$ & $\begin{array}{l}(0.70) \\
-0.013\end{array}$ & $\begin{array}{l}(0.76) \\
-0.067\end{array}$ \\
\hline Offer & $(0.94)$ & $(0.97)$ & $(0.90)$ & $(0.62)$ \\
\hline \multirow[t]{2}{*}{ RET } & -0.041 & -0.037 & -0.026 & -0.025 \\
\hline & $(0.13)$ & $(0.16)$ & $(0.48)$ & $(0.62)$ \\
\hline \multirow[t]{2}{*}{ Loss } & 0.030 & 0.027 & 0.147 & $0.252^{*}$ \\
\hline & $(0.74)$ & $(0.76)$ & $(0.17)$ & $(0.05)$ \\
\hline \multirow[t]{2}{*}{ HHI } & 1.390 & 1.326 & 0.201 & 0.167 \\
\hline & $(0.34)$ & $(0.36)$ & $(0.91)$ & $(0.94)$ \\
\hline \multirow[t]{2}{*}{ OperCycle } & 0.169 & 0.154 & -0.032 & -0.044 \\
\hline & $(0.28)$ & $(0.32)$ & $(0.89)$ & $(0.89)$ \\
\hline \multirow[t]{2}{*}{ BigAudit } & -0.063 & -0.065 & 0.047 & 0.087 \\
\hline & $(0.22)$ & $(0.21)$ & $(0.51)$ & $(0.37)$ \\
\hline \multirow[t]{2}{*}{ Size } & 0.046 & 0.043 & 0.027 & 0.045 \\
\hline & $(0.16)$ & $(0.19)$ & $(0.53)$ & $(0.42)$ \\
\hline \multirow[t]{2}{*}{$\mathrm{BM}$} & $-0.084 * *$ & $-0.085 * * *$ & 0.044 & 0.045 \\
\hline & $(0.01)$ & $(<0.01)$ & $(0.28)$ & $(0.45)$ \\
\hline \multirow[t]{2}{*}{ Log(\#Analysts) } & $-0.059 * * *$ & $-0.058 * * *$ & $0.075 * * *$ & $0.127 * * *$ \\
\hline & $(<0.01)$ & $(<0.01)$ & $(<0.01)$ & $(<0.01)$ \\
\hline \multirow[t]{2}{*}{ LEV } & 0.024 & 0.024 & -0.016 & -0.023 \\
\hline & $(0.31)$ & $(0.32)$ & $(0.65)$ & $(0.66)$ \\
\hline \multirow[t]{2}{*}{ ROA } & 0.132 & 0.077 & -0.099 & -0.173 \\
\hline & $(0.74)$ & $(0.84)$ & $(0.85)$ & $(0.80)$ \\
\hline \multirow[t]{2}{*}{ Chaebol } & 0.036 & 0.037 & 0.041 & 0.094 \\
\hline & $(0.56)$ & $(0.56)$ & $(0.60)$ & $(0.34)$ \\
\hline \multirow[t]{2}{*}{ ForOwn } & -0.004 & -0.001 & 0.014 & 0.081 \\
\hline & $(0.99)$ & $(0.99)$ & $(0.95)$ & $(0.77)$ \\
\hline Year Fixed Effects & Yes & Yes & Yes & Yes \\
\hline Industry Fixed Effects & Yes & Yes & Yes & Yes \\
\hline Observations & 3,362 & 3,362 & 3,362 & 3,362 \\
\hline Pseudo $\mathrm{R}^{2}$ & 0.028 & 0.032 & 0.023 & 0.032 \\
\hline
\end{tabular}

Notes:

This table presents timing of good news and bad news disclosures in relation to labor unions' bargaining schedule. In 
this table, we read all disclosures to identify good, bad, or neutral news using the criteria introduced in Appendix B. We further identify months when a firm makes a good or bad news disclosure and construct firm-month samples. Then we set Qdum as one if a month with disclosures belongs to the second calendar quarter (i.e., April to June), and zero otherwise and then interact it with Union. Panel A is based on the logistic regression estimation using an indicator for at least one good news disclosure in a given month for columns (1) and (2), and using an indicator for at least one bad news disclosure in a given month for columns (3) and (4) as the dependent variable. Panel B is based on the negative binomial regression estimation in which the raw values of good news or bad news disclosure frequency are used as the dependent variable. Regressions include year and industry fixed effects. Standard errors are heteroskedasticity and serial correlation robust, clustered at the firm level. Numbers in parentheses indicate pvalues. $* * * * *$, and $*$ denote the statistical significance at the 1,5 and $10 \%$ levels, respectively (two tailed). All variables are defined in Appendix A. 
Table 6. Endogeneity tests - two stage regression

Panel A. First stage regression

\begin{tabular}{lcc}
\hline Dep. Var $=$ & $(1)$ & $(2)$ \\
& Union & Unionization \\
Existence & Rate \\
\hline Intercept & -12.190 & $-0.637^{* * *}$ \\
Female (Exogenous) & $(0.99)$ & $(<0.01)$ \\
Size & $-0.737^{* * *}$ & $-0.192^{* * *}$ \\
& $(0.01)$ & $(<0.01)$ \\
LEV & $0.230^{* * *}$ & $0.025^{* * *}$ \\
& $(<0.01)$ & $(<0.01)$ \\
ROA & $0.163^{* * *}$ & $0.024^{* * *}$ \\
& $(<0.01)$ & $(<0.01)$ \\
Loss & -0.851 & 0.058 \\
& $(0.12)$ & $(0.53)$ \\
Year Fixed Effects & $-0.196^{*}$ & 0.025 \\
Industry Fixed Effects & $(0.09)$ & $(0.20)$ \\
Observations & Yes & Yes \\
Log Likelihood/Adj. R $^{2}$ & Yes & Yes \\
\hline
\end{tabular}

Panel B. Second stage regression: the relation between disclosure frequency and union strength

\begin{tabular}{|c|c|c|}
\hline \multirow[t]{2}{*}{ Dep. Var $=$} & \multicolumn{2}{|c|}{$\underline{\log (\# \text { Disclosures })}$} \\
\hline & (1) & (2) \\
\hline Union $=$ & Union & Unionization \\
\hline & Existence & Rate \\
\hline Fitted value of Union & $\begin{array}{l}-0.992 * * * \\
(<0.01)\end{array}$ & $\begin{array}{l}-1.465^{* *} \\
(0.03)\end{array}$ \\
\hline Year Fixed Effects & Yes & Yes \\
\hline Industry Fixed Effects & Yes & Yes \\
\hline Observations & 2,084 & 2,084 \\
\hline Adj. $R^{2}$ & 0.393 & 0.384 \\
\hline
\end{tabular}




\section{Table 6 (continued)}

Panel C. Second stage regression: the relation between good news disclosures and union strength

\begin{tabular}{lcc}
\hline Dep. Var $=$ & \multicolumn{2}{c}{$\log (\#$ Good news disclosures) } \\
Union $=$ & $(1)$ & $(2)$ \\
& Union & Unionization \\
Fitted value of Union & Existence & Rate \\
& $-0.875^{* * *}$ & $-0.938^{*}$ \\
Year Fixed Effects & $(<0.01)$ & $(0.09)$ \\
Industry Fixed Effects & Yes & Yes \\
Observations & Yes & Yes \\
Adj.R $\mathrm{R}^{2}$ & 2,084 & 2,084 \\
\hline
\end{tabular}

\section{Notes:}

This table presents the result of 2SLS regressions to control for the possible endogeneity of union strength. Panel A provides the result of the first-stage regression in which Union is the dependent variable and Female is an instrumental variable. Panel B presents the regression of disclosure frequency on Union, while Panel C presents the regression of good news disclosure frequency on Union, where Union is the fitted value in the first stage regression in Panel A. Regressions include intercept, control variables, year and industry fixed effects. Numbers in parentheses indicate $\mathrm{p}$-values. Standard errors are heteroskedasticity and serial correlation robust, clustered at the firm level. ***, $* *$, and $*$ denote the statistical significance at the 1, 5 and $10 \%$ levels, respectively (two tailed). All variables are defined in Appendix A. 
Table 7. Change specifications

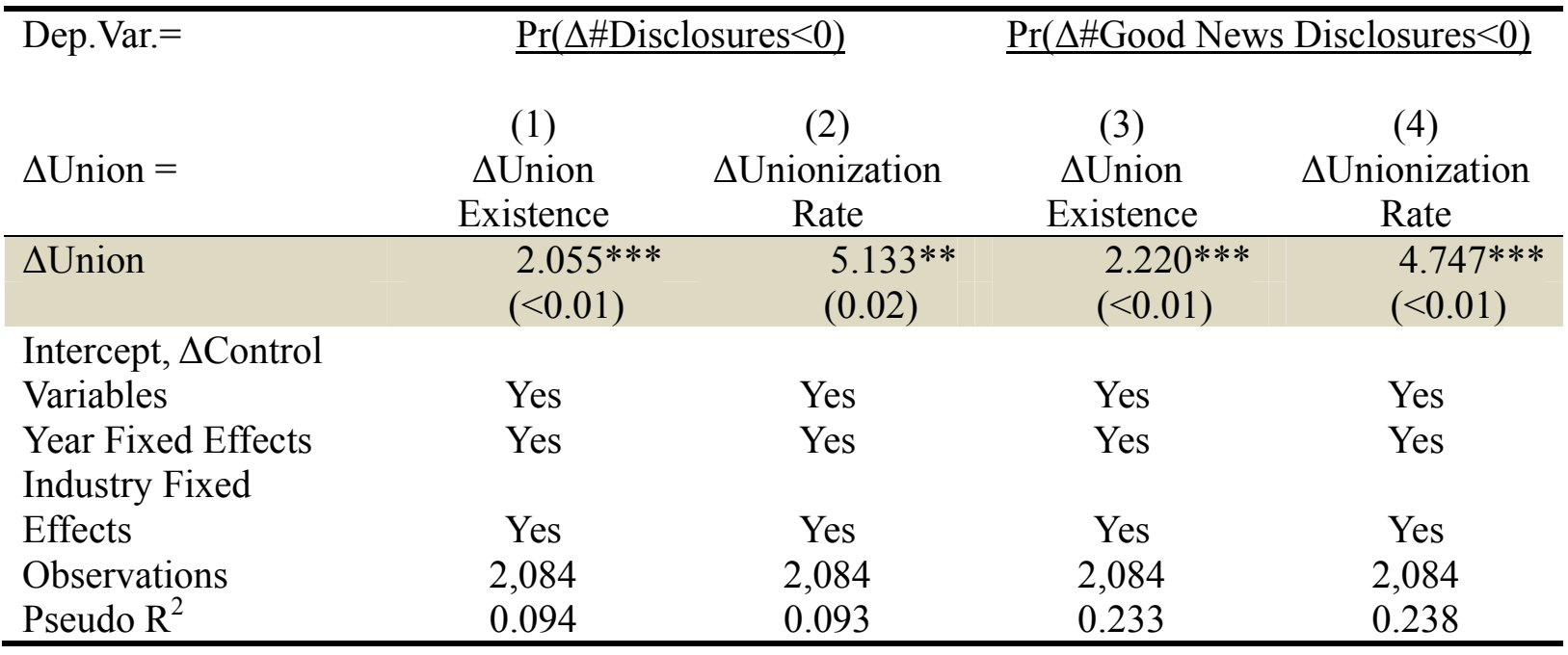

Notes:

This table presents the results of change specifications. It presents the logistic regression estimation results regressing an indicator variable for the decrease in total news disclosure frequency in columns (1) and (2) and for the decrease in good news disclosure frequency in columns (3) and (4) on the change in firm union strength and control variables. Regressions include year and industry fixed effects. Numbers in parentheses indicate p-values. Standard errors are heteroskedasticity and serial correlation robust, clustered at the firm level. ***,**, and * denote the statistical significance at the 1,5 and $10 \%$ levels, respectively (two tailed). All variables are defined in Appendix A. 